\title{
Kongssteinen og navnet Stavanger
}

\begin{abstract}
This article present a new and somewhat daring interpretation of the name Stavanger. Previous discussions have revolved around from which topographical elements the name originates. The suffix ON angr, fjord, predates the Viking Age. ON stafr, standing staff became early an appellative for boundary markers. The King's stone (Kongssteinen) was a remarkable boulder, at least 5.6 meters high and 6.2-7.5 meters wide. In the 4th century, the nearby land was cleared for farming and the boulder became clearly visible from the fjord. The King's stone was one of several hoarstones for an ancient farm, Eiganes, - the parent farm of the town. It balanced on the top of a low mountain ridge (27,4 MASL) above the medieval town. It is discussed whether this boundary marker gave name to the fjord Stavanger, which in the 10th century also became the name of the town.
\end{abstract}

\section{En ny forklaring på navnet Stavanger}

Navnet Stavanger, norrønt Stafangr, er ikke en språklig gåte. Det er sammensatt av to ord: angr, m. norrønt for trang vik, fjord, og stafr, $\mathrm{m}$. stav, stolpe, pilar, merkestav, for eksempel en stående stein eller stokk (Heggstad mfl. 1975:30, 407). Derimot er de topografiske og kulturelle realitetene bak navnet omdiskuterte.

Mange forslag er fremsatt i årenes løp. Den lærde humanisten, presten og historikeren i Bergen Absalon Pedersen Beyer (1528-1575) fra Aurland presenterte den første kjente teorien i sitt verk Om Norgis Rige fra 1567. Han mente Stavanger opprinnelig het «Stadander». Det betydde bokstavelig «den andre staden» (by nummer to). Ifølge Snorres kongesagaer, som Absalon kjente, var nemlig Tønsberg den «første staden» i Norge (Storm 1895:113-114). Absalons fantasifulle «nr. 2»-teori er for lengst skrotet på språkhistorisk grunnlag (Ersland og Solli 2012:46). ${ }^{1}$

Historikeren Tormod Torfæus (1636-1719) på Karmøy presenterte i 1711 en annen forklaring på byens navn. Torfæus var kongelig Historiographus fra $1682 \mathrm{og}$ en av sin tids mest kunnskapsrike personer. Tradisjonelt er han tolket dithen at han skal ha ment at Stavanger var oppkalt etter et skjær, Stavanger Steen, i havneområdet Østervåg. I sin originale tekst benyttet imidlertid Torfæus ordet scopulo (Torfæi 1711:64), som på latin ikke betyr «skjær», men snarere «sjømerke, nes, berg eller stein» («a projecting rock») (Glare 
1982:1708). Torfæus synes dermed å ha ment at stavelementet i Stavanger hadde sammenheng med en formasjon man peilet etter. ${ }^{2}$

I nyere tid har spørsmålene dreid seg om hvilken fjord og hvilken stav navnet henviser til. Det har vært mange forslag om både fjorden og staven: Byfjorden (Flokenes 1999), Vågen (Helle 1975), Østervåg $\rightarrow$ Breiavatnet (Hovda 1964) og Hillevågsvatnet (Engen 1955), og staven: eikestaver (Bringsfjord 2009), Valberget (Elgvin 1956; Hovda 1964; Helle 1975; Særheim 2007), berget mot Østervåg (Elgvin 1956; Hovda 1964), Kalhammarodden (Solheim 1940) og Vågens «rette løp» (Erichsen udat. [ca. 1905]; Brøgger 1915; Kjær og Rygh 1919:245-246; Stemshaug 1985).

På tryggest grunn står likevel historiker og filolog Knut Helle med sin hypotese om at Valberget var staven og Vågen fjorden (jf. Ersland og Solli 2012:46-50). For Helle var det primært formen på Valberget som minnet om en stav. Sekundært kunne stående kvartsitt i Valberget «... på nærmere hold ha forsterket det vertikale stav-inntrykket ...» (Helle 1975:33) (figur 1). Helle utelukket ikke andre mer eller mindre steile berg i området, slik som Kalhammeren. Han fant likevel at avstanden på omkring $1 \mathrm{~km}$ «... til munningen av den egentlige Vågen» svekket denne muligheten (Helle 1975:33).

Jeg slutter meg til at Vågen var fjorden, men vil her presentere et nytt forslag til staven. Det tar utgangspunkt i den såkalte Kongssteinen - en nå for lengst fjernet kampestein på toppen av Risberget ovenfor Breiavatnet i Stavanger (figur 2). Den var både et grensemerke mellom gårdene i området-en stav-og en god peilestein fra fjorden. Hovedproblemstillingen i denne artikkelen er om Kongssteinen kan ha gitt navn til Stavanger.

Kongssteinen var et markant landemerke. Lenge var den Stavangers fremste attraksjon sammen med Domkirken (Austbø mfl. (red.) 2008:278-279). Den fikk sitt fornemme navn etter et besøk av kong Fredrik IV i 1704. Kongssteinen var ca. 5,65 m høy i øst og målte 7,53 $\mathrm{m} \mathrm{N}-\mathrm{S}$ og 6,20 $\mathrm{m}$ Ø-V (tabell 1). ${ }^{3}$ Den balanserte på et «fundament», etter W.F.K. Christies 1828-tegning sannsynligvis en langsgående forhøyning i berget, ca. 4,4 m lang og 32-33 cm bred ( 7 x 0,5 alen) (figur 3c). Steinen, som var av granitt, ble fjernet i flere omganger før siste sprengning antakelig fant sted i 1890 -årene. ${ }^{4} \mathrm{Da}$ byens område ble utvidet mot øst i 1848, ble Kongssteinen stående i bygrensen mot Hetland. Men som vi skal se, var den allerede i 1686 grensestein mellom gårdene Hetland og Eiganes øde - en nå forsvunnet ødegård i området ved Paradis (Bærheim 1959). Selv om Kongssteinen var godt synlig fra Vågen, har den hittil ikke vært trukket inn i diskusjonen omkring navnet Stavanger.

Helle diskuterte bynavnet inngående i sitt verk om Stavanger fra 1975. Han pekte på at stafr i middelalderkilder ble brukt om «stående formasjoner konkret av tre eller stein» og i overført betydning om «bokstaver eller striper i seil». Stafr ble brukt om grensemerker for en gårds samlede territorium, en betydning som er særlig godt kjent i Rogaland og Agder, der dialektord som stavsto og stabbsto i middelalderen og nyere tid betegnet slike grensesteiner. Naturlig lagte steiner, eller fjelltopper, utgjorde gjerne hjørnemerker i skifter mellom gårder (Helle 1975:19). Helle fant likevel ikke en slik grensestav ved Stavanger. Han landet derfor på et annet alternativ, nemlig Valberget, slik også Johannes Elgvin hadde foreslått i sin byhistorie (Elgvin 1956:48). Fra fjorden kunne dette steile berget minne om en stav i overført betydning. Helle var ikke oppmerksom på Kongssteinen, som ikke omtales i hans grundige verk.

Kampesteiner på bestemte steder i landskapet var tidligere utgangspunkt for siktlinjer hvorved man skilte gårdsvaldene fra hverandre (Hovstad 1980). Med tiden ble grensene 


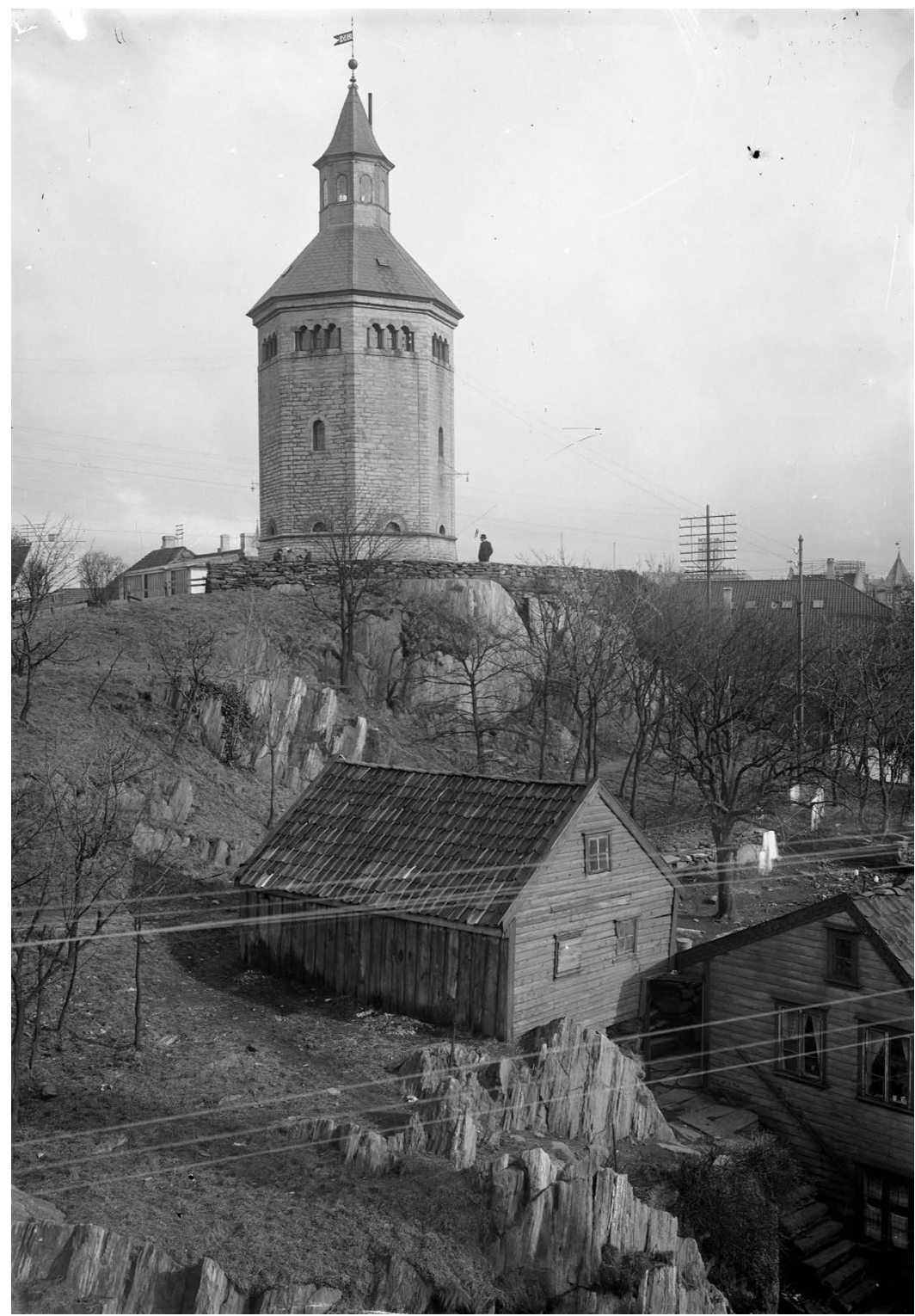

Figur 1: Valberget. Geologien i Stavanger er dominert av omdannede bergarter som en gang var sand og leire, og som er blitt til kvartsitter og skifere. Lagene er foldet sammen, derfor er de så steile. Det er ganske vanlig at hvert enkelt lag kan følges bortover i terrenget, som vi ser på bildet av denne ryggen med steil lagning. Knut Helle har utformet den rådende teorien om Stavanger-navnet. Han mente at formen på Valberget i Stavanger minnet om en stav. Dette berget ga navn til fjorden (-angr), «stav-fjorden», som igjen ga navn til byen. Den stående formen på kvartsitten i berget mente han forsterket inntrykket av en stav. Foto: Gunnar Wareberg, før 1917. Stavanger byarkiv. 

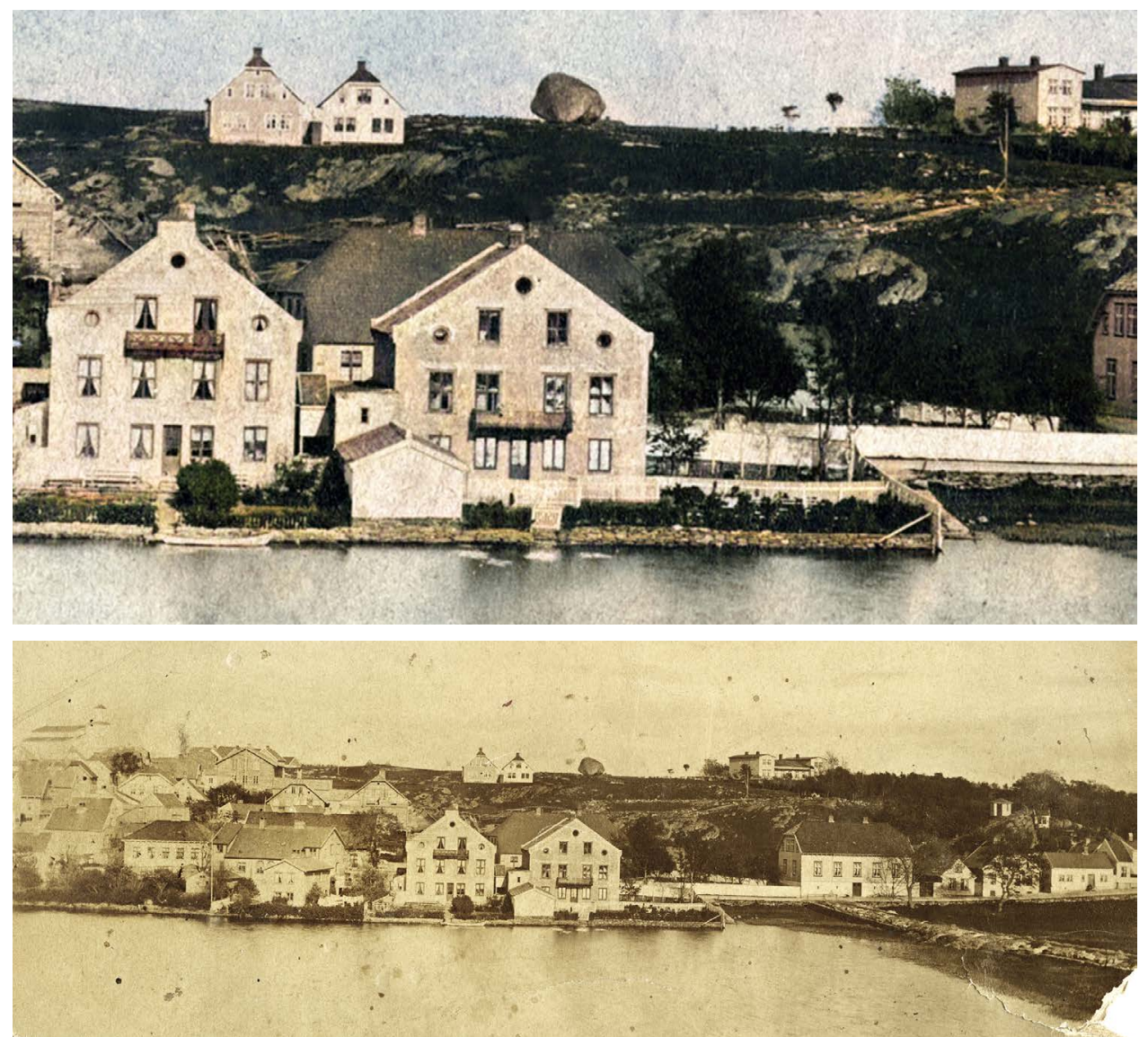

Figur 2: Kongssteinen på Risberget ovenfor Breiavatnet i Stavanger i slutten av 1860-årene. Topograf Lars Hess Bing (1796:659-660) omtalte Kongssteinen som «... en moegtig stor rund Steen, ligesom paa en Kiøl, der ballancerer paa sin egen Vagt». Nederst: utsnitt av foto vedlagt Formannskapsprotokollen fra 1949. Øverst: forstørret utsnitt, kunstig farget av Kjetil Loftsgarden. Ukjent fotograf. Stavanger byarkiv.

fastere, først i innmark, siden i utmark og skog, der nøyaktige grenser lenge var mindre viktige. I 1686 var det strid om grensen mellom Eiganes øde og Lagård. «Eiganesmarka» var i 1607 blitt byens mark, og Lagård, som i middelalderen trolig var lager- og oppsamlingsplass for biskopens inntekter fra Stavanger stift, var kjøpt av den nye amtmannen, Daniel Knoff (1614-1687), i 1685. Sannsynligvis er Kongssteinen identisk med en «stor Steen» som nevnes i grenseoppgangen i 1686.

Jeg viser i denne artikkelen at Kongssteinen på Risberget var én av hjørnestavene for en stor, eldre Eiganes gård, og at den sto i delet mot Hetland. Den var én av flere slike flyttblokker som markerte Eiganes' gamle grense. Ved hjelp av en 3D-landskapsmodell demonstrerer jeg at Kongssteinen var godt synlig fra Vågen. ${ }^{5}$ Fri sikt fra Vågen forutsetter et åpent 
åker- og beitelandskap omkring Breiavatnet. Analyser av pollen avsatt i Breiavatnet indikerer nettopp et slik åpent jordbrukslandskap alt fra 300-tallet, med noen gjengroingsperioder senere (Simonsen 1971, 2013).

Fra en båt midt i Vågen ville Kongssteinen være godt synlig i horisonten. I siktlinjen lå kampesteinen mellom høydene Storhaug til venstre og Varden til høyre, og den hadde ingen fjell bakom som reduserte synligheten. Min hypotese er at den spesielle utsikten fra Vågen var navngivende for fjorden - bokstavelig «stav-fjorden», med meningen: «fjorden ved staven» eller «fjorden der staven sees». Dette forutsetter at ordet staf enten ble benyttet som fellesord (appellativ) for gårdsgrensemerker da navnet Stavanger ble dannet, eller at formen på Kongssteinen kunne minne om en stav karakteristisk nok til å gi navn til fjorden.

Tidligere byhistorikere har ikke vært oppmerksomme på Kongssteinens iøynefallende plassering øverst på Risberget. Hverken arkeologene A.W. Brøgger (1915) eller Jan Petersen (1925) omtaler den i sine byhistorier. Elgvin (1956) nevner den så vidt i annen kontekst. Det gjør også historikerne Geir Atle Ersland og Arne Solli i Stavanger bys historie, fra 2012. Heller ikke filologer og stedsnavnspesialister som har drøftet Stavanger-navnet særskilt, har fått med seg Kongssteinen (Rygh 1896; Hovda 1964; Holm 1991). ${ }^{6}$ Ersland og Helle har mange gode og nyttige drøftinger av faghistoriske teorier og nær sagt alle tenkelige sider ved Stavanger-navnet. Jeg trekker veksler på deres grundige forskning.

Jeg har også hatt nytte av Oluf Ryghs (1896) klassiker Norske Fjordnavne, Oddvar Nes' (1976) Fjordnamn og Per Hovdas arbeid med Stavanger-navnet (1964) samt lokallitteratur (Erichsen udat. [ca. 1905]; Henriksen 1953 [1908]; Brøgger 1912; Solheim 1940; Bærheim 1953, 1959; Myhre 1953; Midbrød 1960; Bringsfjord 2009; Frafjord 2009). Kongssteinen har imidlertid fått ufortjent lite oppmerksomhet i forskningen, med unntak av en liten artikkel fra 2016 av arkeolog Sveinung Bang-Andersen og spredte glimt i lokal litteratur.

\section{Bakgrunn}

Stavanger ble utskilt fra omkringliggende bondeland senest på 1100-tallet. En eldre samlingsplass av noe slag synes da å ha blitt både bispesete og by (Munch 1943 [1855]:50). Stavanger ble på et tidspunkt en selvstendig jurisdiksjon, og hadde trolig også en egen bylov, slik som andre middelalderbyer. Kong Håkon Håkonsson bekreftet i $1233^{7}$ kong Magnus Erlingssons gave av Stavanger til Gud og St. Svithun en gang mellom 1161 og 1184. Kongsgaven gjaldt «boeen sialvan Stafang», det vil si «selve byen Stavanger» (Helle 1975:83-84). Biskopen og domkapitlet som rådet over Domkirken, kom slik til å forvalte Stavanger gjennom middelalderen (RN I nr. 628; Ersland og Solli 2012). Navnet Stavanger er imidlertid langt eldre enn byen, trolig dannet alt i eldre jernalder.

Stafangr dukker opp i kvadet Hrynhenda, diktet av Arnor Jarleskald kort tid etter 1042. Vi kjenner to andre gårder i Norge som het Stavanger: Stavang i Florø og Stong i Askvoll (Ersland og Solli 2012:49). Det er usikkert om kvadet refererer til vårt Stavanger eller til en av gårdene i Sunnfjord. Det eldste belegget for vår by finnes i et pavebrev fra 1154, i latinisert form: Stawangriensem, og da egentlig om bispedømmet (DN VIII nr. 1).

I eldre nordisk språk må angr ha vært et fellesnavn (appellativ) for fjorder og våger. I og med at ordet angr ikke lenger var i bruk da det fjordrike Island ble kolonisert fra 872, mener språkforskere at det må være eldre enn vikingtiden (Helle 1975:12). Den svenske stedsnavngranskeren Gösta Holm (1991) har gjort den grundigste studien av de nordiske angr- 
navnene. Holm konkluderer med at de temmelig sikkert er eldre enn vikingtiden. I de nordligste delene av Skandinavia kan navneleddet fremdeles ha vært i bruk vikingtiden. Følger vi Holm, må vi anta at navnet Stavanger helst ble dannet i siste del av eldre jernalder (1-575 e.Kr.), altså på den tiden da det etter pollenanalysene å dømme ble ryddet en gård ved Breiavatnet (Simonsen 1971; 2013).

Navnet har vært forsøkt forklart ut fra topografiske forhold. Brøgger pekte på Vågen som både fjorden og staven; det var «den temmelig smale vaags rette løp» som lå bak navnet (Brøgger 1915:2). Rektor ved Stavanger katedralskole Andreas Emil Erichsen hadde foreslått en slik tolkning omkring 1905, at navnet utvilsomt betød «... den rette, ligeløbende Fjord» (Erichsen udat. [ca. 1905]:5). Både Erichsen og Brøggers forklaring, som Brøgger hadde fra språkforsker Magnus Olsen, forutsetter at staven lå flatt. Det var fjordens retthet som ble assosiert med en stav. En liggende stav er språkteoretisk ikke umulig, men samsvarer ikke optimalt med den fysiske grunnbetydningen av ordet stav, nemlig en oppreist stein eller stokk.

Språkforsker Kåre Flokenes (1999) fremsatte for 20 år siden et nytt forslag til fjorden i navnet. I boka Stadnamn i Askvoll sammenliknet han, slik som Helle, topografiske trekk ved de tre stedene med Stavanger-navn. Flokenes kom frem til et helt annet resultat enn Helle, som han polemiserte mot. Stavanger var en eldre betegnelse for Byfjorden, ikke Vågen. Flokenes la vekt på at fjordene fikk navn av sjøfarende og «... inneheld opplysningar både om rette (eller beine) strandliner og reint farvatn i eit område som er så langt som staven rekk ...» (Flokenes 1999:27). Det rette fjordstykket fra Tungenes og innover var navngivende for Stavanger. Den språkteoretiske begrunnelsen var den samme som Brøgger og Olsen ga for Vågen, men ble nå overført på den større Byfjorden. Staven ble fremdeles liggende.

Flokenes forstår Stavanger-navnet som et eksonym. Navnet ble gitt av sjøfarende (underforstått fremmede), ikke av lokalbefolkningen. Ingen Stavanger-navn er imidlertid bevart som fjordnavn i dag. Samtlige har gått over til å betegne gårder og bosetninger på land (Rygh 1898:34). Dersom dette var sentrale navn for sjøfarende, slik Flokenes hevder, skulle vi kanskje forvente at navnene var bevart som fjordnavn; det er de ikke. Det kan tyde på at navnene ble gitt lokalt, og er endonymer, slik også Ersland har påpekt (Ersland og Solli 2012:50-51).

I tostavings angr-navn har første ledd en adjektivisk funksjon for andreleddet, og beskriver med andre ord en egenskap ved fjorden (Nes 1976; Frafjord 2009). I Norske Fjordnavne oppgir Rygh 73 eldre fjordnavn med suffikset -angr (Rygh 1898:68-78). Mange av prefiksene beskriver trekk ved fjordene. Det kan være en «iboende egenskap» som for eksempel lang (Langangen) og smal (norrønt mjór) (Mjøanger), men vanligere har fjordene navn etter noe på land: eid (Eidanger), eik (Eikanger), fjell (Fjellanger) og torv (Torvanger), for å nevne noen. Flokenes postulerer at sjøfarende ville oppfatte Byfjorden som såpass snorrett at den kunne assosieres med en liggende stav. Det dreier seg da om søndre side av fjorden. På topografisk grunnlag kan det innvendes at siktlinjen brytes av Grødemhammeren. Det mangler fjell og steile åsrygger som kunne forsterke inntrykket av Byfjorden som en rett fjord.

På eldre sjøkart er Byfjorden ikke fremstilt som en rett fjord. To sjøkart fra 1589 og 1592 av den hollandske kartografen Lucas J. Waghenaer (1534-1606) viser kysten fra Jæren til Bergen og fra Agder til Hordaland. Byfjorden er på ingen måte tegnet inn som en rett fjord, 
snarere tvert om. Den likner en bukt med bølgende former som viser ankringsplasser som Dusavika. Kartene var ment for sjøfart med store seilskuter og tilpasset datidens maritime behov. Viktigere enn kystlinjen var sjømerker, havner og skjær. Isolert sett er dette naturligvis ikke et absolutt argument. Men når vi i tillegg vet at Byfjorden tidligere het Brofjord (kart fra 1650-1680), helst etter øya Bru, virker det hele lite sannsynlig. ${ }^{8}$ Navnet Bru (Brua, 1273), *brú, er trolig en sideform til brún f., skarp kant (NG X:267), og refererer nok til Brufjellets vestkant mot Hausen, som er skarp og noe utypisk for området. Det er fullt mulig at «Brufjorden» over tid ble omdannet til det relativt likelydende «Byfjorden», uten at det skal drøftes nærmere her.

I sum virker Flokenes' forslag lite sannsynlig. Jeg slutter meg derfor til det alminnelige synspunkt at Vågen var fjorden i navnet. Navnet «Indre Vågen» (idra uaginn) dukker for øvrig opp i manuskripter fra ca. 1300 i forbindelse med hendelser i Stavanger i 1207 (Magerøy 1988:100). Også andre forslag enn Vågen har vært fremsatt, men der henviser jeg til Helle og Ersland, som har redegjort for mulighetene og avvist dem på troverdig grunnlag.

\section{Kongssteinen}

Da iskappen over Skandinavia smeltet for knapt 12000 år siden, ble den store, kantete, men noe ovalformede flyttblokken liggende og balansere øverst på en bergrygg. I mange tusen år var Kongssteinen et landskapselement som det var vanskelig å overse, særlig etter at skogen var ryddet i området i eldre jernalder (Simonsen 2013). Det finnes flere slike spektakulære flyttblokker fra istiden i Norden. Kongssteinen kan i størrelse sammenliknes med den mektige balansesteinen Kummakivi «merkelig stein» i Finland, nær grensen mellom de historiske landskapene Savolax og Karelen (figur 3a).

Kongssteinen er inntegnet og usedvanlig detaljert beskrevet på et Stavanger-kart fra 1726 av by- og rådstueskriver Ulric Frideric Aagaard, som også laget to tegninger av den ti år senere (Nissen 1962) (figur 4). Aagaard gjorde noe tilsynelatende merkelig da han laget Stavanger-kartet. På et lite vignettkart øverst i venstre hjørne tegnet han inn Kongssteinen i detalj og anga nøyaktige mål på steinens syv flater, under tittelen Kongssteenens faciat, Accurate Maal og beskrivelse. Dette var ment som en gest til kong Fredrik og et minne om kongens Stavanger-besøk i 1704.

Tegningene av Kongssteinen fra 1736 er mindre kjente. Den ene er oppbevart i Deichmanske bibliotek i Oslo (K 74) (figur 4, nederst), den andre i Det Kongelige Bibliotek i København. Opplysningene varierer litt på kartet og tegningene. Det fremgår at Aagaard hadde tatt opp målene i 1708 (Nissen 1962:128, 153-154). Den fremtredende plassen Kongssteinen fikk på 1726-kartet, og de fete typene som ble brukt, var åpenbart en hyllest til kongen. Det var en smigrende beskjed fra Stavanger om at steinen var oppkalt etter ham. Aagaard arbeidet som sorenskriver i Rådstuen i Stavanger inntil 1731. Kartet må ha vært tiltenkt et kongelig atlas. Det inngår nå i kong Fredrik Vs (1723-1766) praktfulle og voluminøse atlas, Novus Atlas Danice, ferdigstilt 31. mars 1761 til denne kongens 38-årsdag (bind 40:70). Atlaset inneholder kart fra hele verden og fra alle kongelige slott, borger og kjøpsteder i riket.

Amtmann Bendix Christian de Fine (1696-1746) gir omkring 1745 forklaringen på navnet Kongssteinen. Kong Fredrik IV (1671-1730) besøkte steinen i 1704. de Fine skriver: «Kong Friderich den Fierde tog selv samme merkelige Steen i øyesyn da hand 1704 benaa- 

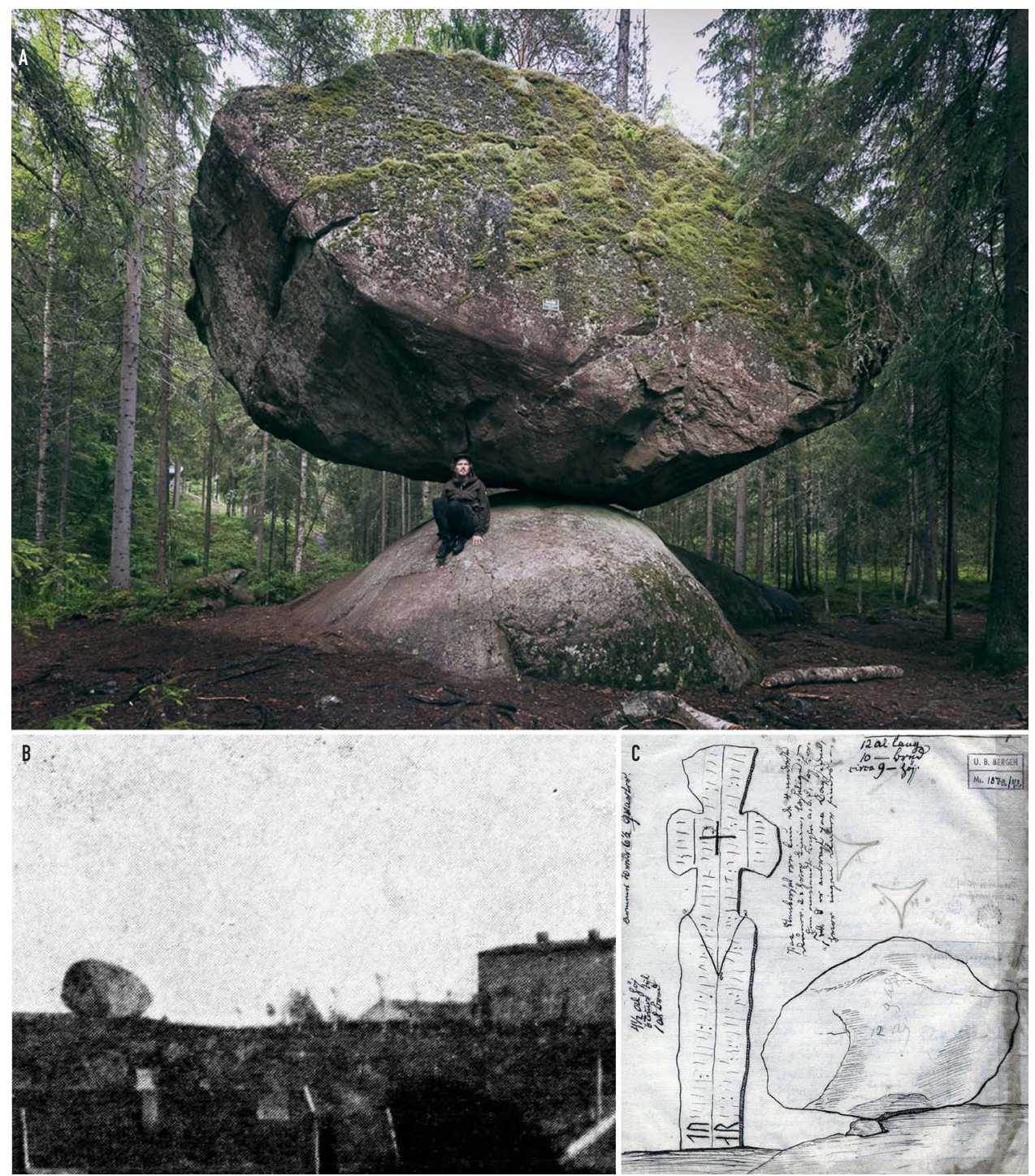

Figur 3: Kongssteinen i Stavanger (B og C) kan i størrelse sammenliknes med (A) kampesteinen Kummakivi, Ruokolahti, Finland $(7 \times 4 \times 5 \mathrm{~m})$. Kongssteinen var noe større. (A) Foto: Jussi Judin, CC-BY-SA 3.0. (B) Utsnitt av foto av Kongssteinen i årene før ca. 1865 (etter Henriksen 1953 [1908]:137). (C) W.F.K. Christies tegning av Erling Skjalgsson-korset og Kongssteinen, fra reise til Stavanger 28.-31. mars 1828. Han oppfattet den som en ruggestein. Det feilaktige størrelsesforholdet på tegningen bidro neppe til stor antikvarisk interesse. Universitetsbiblioteket i Bergen. 

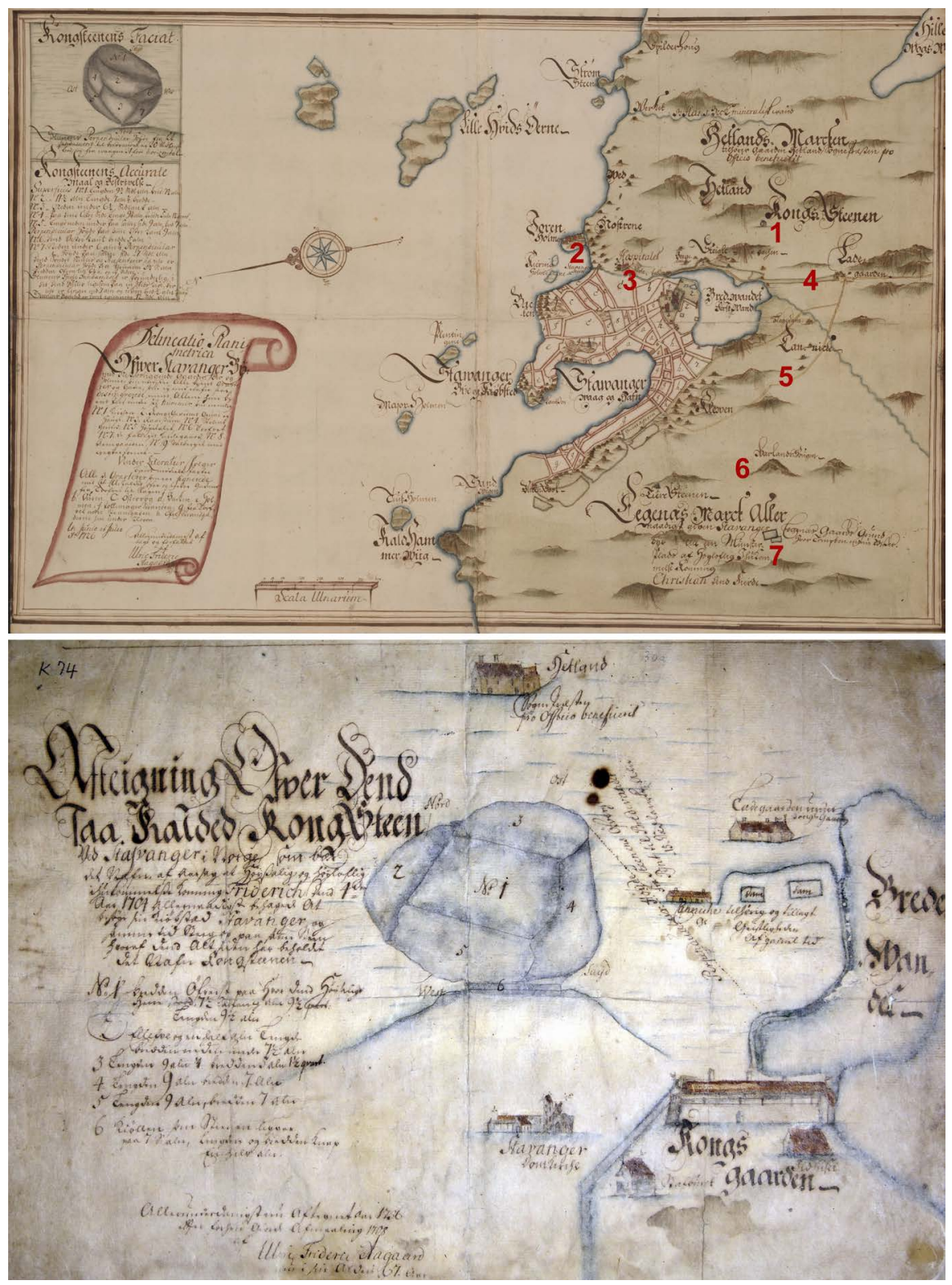

Figur 4: Øverst Ulric Frideric Aagaards Stavanger-kart fra 1726 var tiltenkt et kongelig atlas. Kongssteinen $i$ vignettkart øverst til venstre var en hyllest til kong Fredrik IV, som hadde besøkt Stavanger og Kongssteinen i 1704. Viktige steder som diskuteres i teksten, er avmerket:

1. Kongssteinen, 2. Stavanger Steen, 3. Skolebekken, 4. Lagårds «doble steingjerde» og innfart til byen, 5. Løkkeveien, middelalderbyens sannsynlige grense, 6. Vålandshaugen, 7. Tufter på det nedlagte tunet for Eiganes gård. Det Kongelige Bibliotek, København. Nederst Aagaards «Teigning Over Dend Saa Kalded Kongsteen» 1736. Deichmanske bibliotek. 
dede Byen med sin høye nærværelse ...». Den er fra «... den tiid af bleven kaldet Kongs Steenen» (de Fine 1952:92). ${ }^{9}$

En stund fikk Kongssteinen stå i fred i den nye bygrensen fra 1848, frem til 1880-årene da det ble etablert et nytt gatenett ved Breiavatnet. Kaptein og konduktør Christian Fredrik Torstrup (1814-1908) utarbeidet i tiårene før Kongssteinen forsvant, et nøyaktig bykart over Stavanger i årene 1863-1866. Dermed er kampesteinens presise posisjon kjent.

Kongssteinen er også dokumentert på minst fire eldre fotografier fra 1860-årene, på to malerier, ett fra 1854 (Suckow, ukjent) og dessuten på Gabriel Monsens akvarell «Mot Bergeland» fra 1871 (på Stavanger museum), i tillegg til på en kullstifttegning «Stavanger» fra 1853, sett fra Våland (signert J.N.P. 15/8-53). ${ }^{10}$ Dessuten viser arkitekt Franz Wilhelm Schiertz' skisse utsyn mot nord fra toppen av steinen i 1842 (Enoksen mfl. (red.) 1944:10) (figur 5).

Fotografiene og maleriene gir et godt inntrykk av hvor ruvende Kongssteinen var i bybildet. I tillegg til på Kaptein Torstrups bykart, er Kongssteinen presist angitt i dagens gatenett på Reguleringsplan 32 fra juni 1875 (Stavanger byarkiv). Den er også angitt på kart over Hetlandsmarken 1843 og på «Detaljkart over Stavanger, ca. 1880», som viser siste rest før sprengningen i 1890-årene (begge Stavanger byarkiv). Vi finner den også på et kroki «Plan af Stavanger» utarbeidet av L. Bryn som «Fölgeblad» i Carl Lous' «En stavangersk Cicerone» 1868.

Vi vet derfor at den sto ved det sørøstre hjørnet av Kongssteinsgate 57, der gateplanet måler 27,4 m over havet (moh.). Kongssteinen raget ca. 33 moh. Det er et viktig poeng når vi om litt skal analysere hvorfra steinen kunne sees. Til sammenlikning er Valberg 29 moh., Varden 56,2 moh., Storhaug 43,7 moh. og toppen av Olavskleiva 28,4 moh. Men først skal vi undersøke Eiganes' gamle gårdsgrense for også å belyse lokal tradisjon med å bruke store steiner for å markere gårdsgrenser.

\section{Staver og grensemerker for Eiganes gård}

I det følgende skal vi undersøke grensene for den antatte opphavsgården for Stavanger, nemlig Eiganes, vest for byen. Denne gjennomgangen viser at Kongssteinen sto på grensen mellom Eiganes og Hetland.

Den 8. august 1607 skjenket kong Kristian IV Stavanger «en plads» utenfor byen kalt «Egisnes». Den skulle være til «evindelig Eie» av «Vor Kjøbsted Stavanger» (NRR IV:225). Det var en sårt tiltrengt utvidelse av byens jurisdiksjonsområde. Kongens intensjon var først og fremst å skaffe borgerbevæpningen i Stavanger en ekserserplass. Tidligere omfattet byens takmark bare det bebygde området og løkkene omkring. I sør og vest var byområdet trolig avgrenset av den gamle Løkkeveien. ${ }^{11}$ Helle (1975:145) antyder at «Rådstuens rett», det vil si byloven, tidlig på 1600-tallet gjaldt på Strandsiden, området ved Olavskleivå og rundt Breiavatnet, men også Kannikgjerdet og Pedersgjerdet mot Hetland. Rektor Erichsen opplyser klart og tydelig at Skolebekken og Breiavatnet utgjorde grensen i øst, der Breiavatnet tilhørte byen (Erichsen udat. [ca. 1905]:18).

Trolig er det Kanniket med mer som er nevnt som en «plaz» sør for Breiavatnet i 1322 (DN III nr. 132). Bård Petersson skjenket da plassen for evig årtidhold i St. Svithun kirke av kannikene for ham, fruen og hennes mor. Bård Petersson var ingen hvemsomhelst. Han var kongens skriver 1297-1319 og gulatingslagmann og fehirde 1322-1334, og synes privat å 

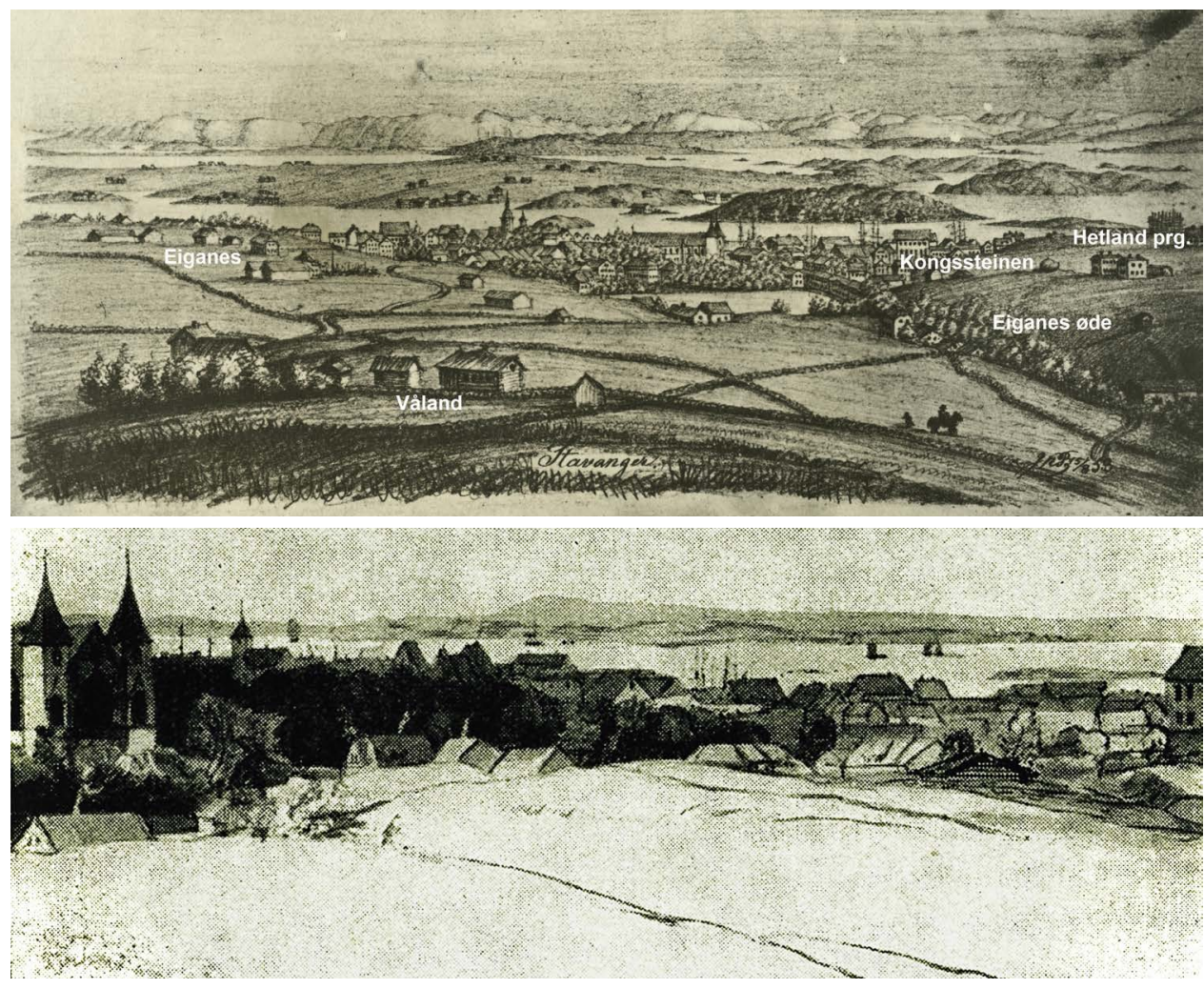

Figur 5: Øverst, kullstifttegningen «Stavanger» sett fra Våland i 1853. Vi ser markene til Eiganes (øvre halvdel), Lagård (ncermest, nedre del) og Hetland (lengst til høyre bak den nylig oppførte Hetland prestegård). Kongssteinen sees tydelig til høyre på tegningen (mer enn $1 \mathrm{~km}$ unna). Ukjent, signert JNP 15/8 1853. Stavanger byarkiv. Nederst, utsyn fra toppen av Kongssteinen 1842 mot nord. Rennesøy i midten bak med Hundvåg og byøyene foran. Domkirken og Valbergstårnet til venstre. Skisse ved arkitekt Franz Wilhelm Schiertz (18131887), gjengitt etter Enoksen mfl. (red.) (1944:10).

ha eid en part av Eiganes. Trolig må en slik gave ha tilfalt både biskopen og kannikene i og med at årtidholdet skulle finne sted i biskopskirken (St. Svithun). Det kan være viktig når vi om litt skal diskutere grensene mellom Lagård, Eiganes øde og Kanniket.

Et kart tatt opp over Eiganes i 1830 gir god hjelp til å rekonstruere grensen mer nøyaktig (figur 6). ${ }^{12}$ Både fra dette kartet og grenseoppgangsssaker fra 1686 og 1855 blir det klart at Eiganes' grenser ble trukket opp mellom store stavsteiner. Flere gamle grensesteiner er kjent og fremdeles bevart (figur 8). Vår rundtur starter ved Kalhammer. Vi arbeider oss motsols langs grensen ned til Paradis ved foten av Storhaug. Grensen fra Kalhammer til Klovsteinen, det vil si Eiganes' grense mot Tasta, Stokka og Tjensvoll, er gitt av bygrensen før 1848 og en merkegangsforretning i 1835. Strekningen fra Hillvågsbekken ved Mosvatnet til Paradis er beskrevet i merkegangsforretningen fra 1686 der grensen for Lagård ble gått 

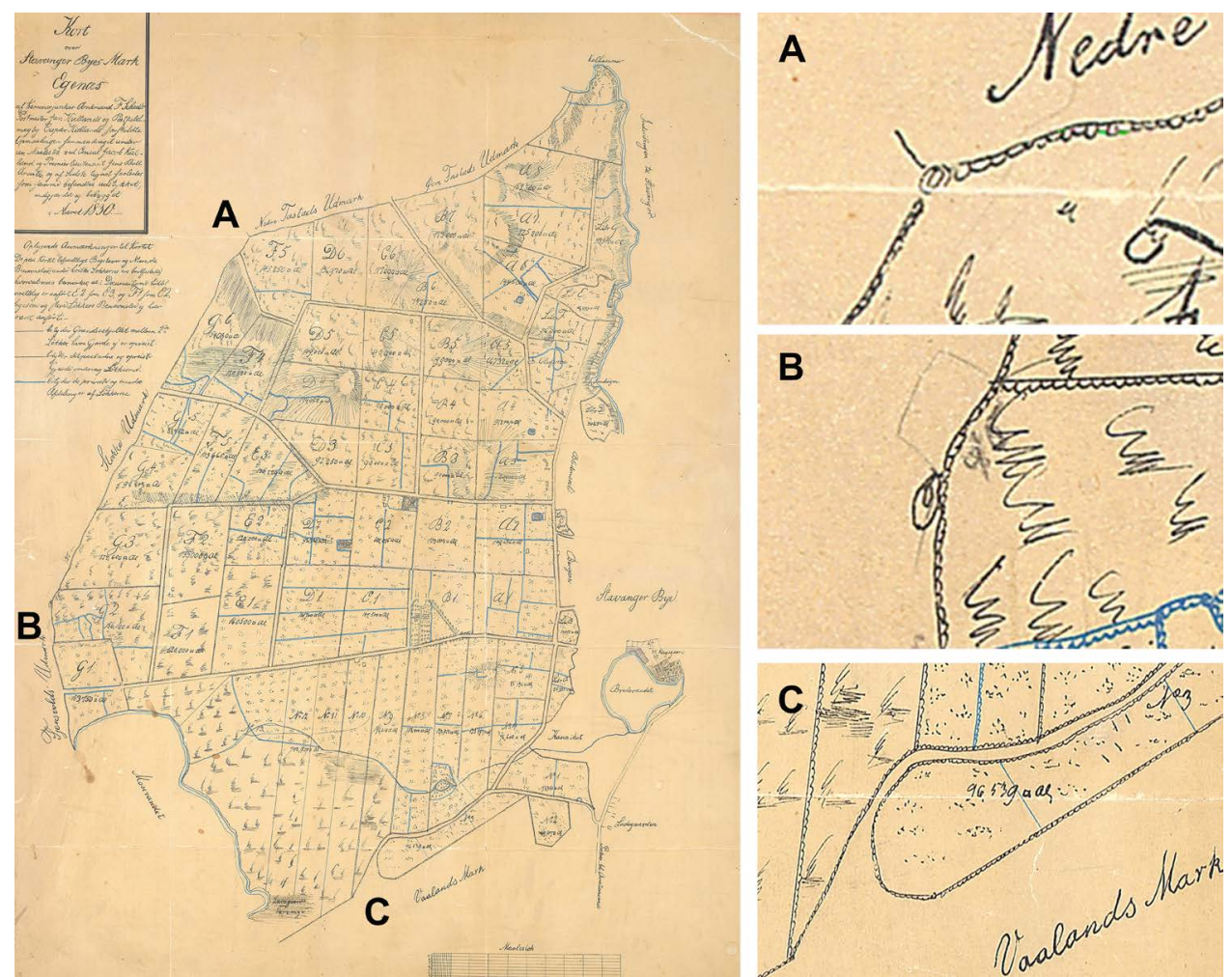

Figur 6: Kart over Eiganes 1830. Byens tidligere fellesområde ble nå privatisert og oppdelt i løkker som ble bygslet bort til bemidlede borgere. Kartet har flere interessante detaljer. Blant annet er (A) Kutmandssteinen og (B) Klovsteinen inntegnet, men ikke navngitt, og dessuten (C) en stor geil ved Vålands mark samt krøtterveiene til og fra Lagård eller byens marked og havner (Vågen og Østervåg). Navnet «Studestredet» («Okseveien») (nå forsvunnet) i Lagårds utmark 1778 indikerer en slik krøttervei (Barheim 1959:98). Stavanger byarkiv.

opp. En del vanskeligheter oppstår i området for Lagård gravlund og Paradis, der Eiganes øde og Kongssteinen lå. Dette området må vi derfor undersøke noe grundigere. Merkegangsforretningen er publisert av lokalhistoriker Anders Bærheim (1959) i Stavanger museums årbok 1958, side 85-95. Vi ser nærmere på grenselinjen.

(1) Fra Kalhammer ved Byfjorden gikk grensen til Byhaugen. Der treffer vi vår første grensestein, en stor flyttblokk som i 1835 kalles «Kutmandsstenen» (i dag «Knutmannsteinen») (figur 7). Den er avmerket uten navn på kartet fra 1830. På jysk dansk betegnet Kutmand, tidligere fuglen gjøk (Molbech 1833:623). Det er likevel lite ved steinblokken som minner om en fugl. I grenseoppgangen i 1835 henvises det også til en eldre merkegangsforretning av 23. mai 1755: «... i hvilken det antydes at Stokke Gaards Mark grændser mod Egenæs fra Kløfstenen til Kutmandsstenen ...». ${ }^{13}$ 

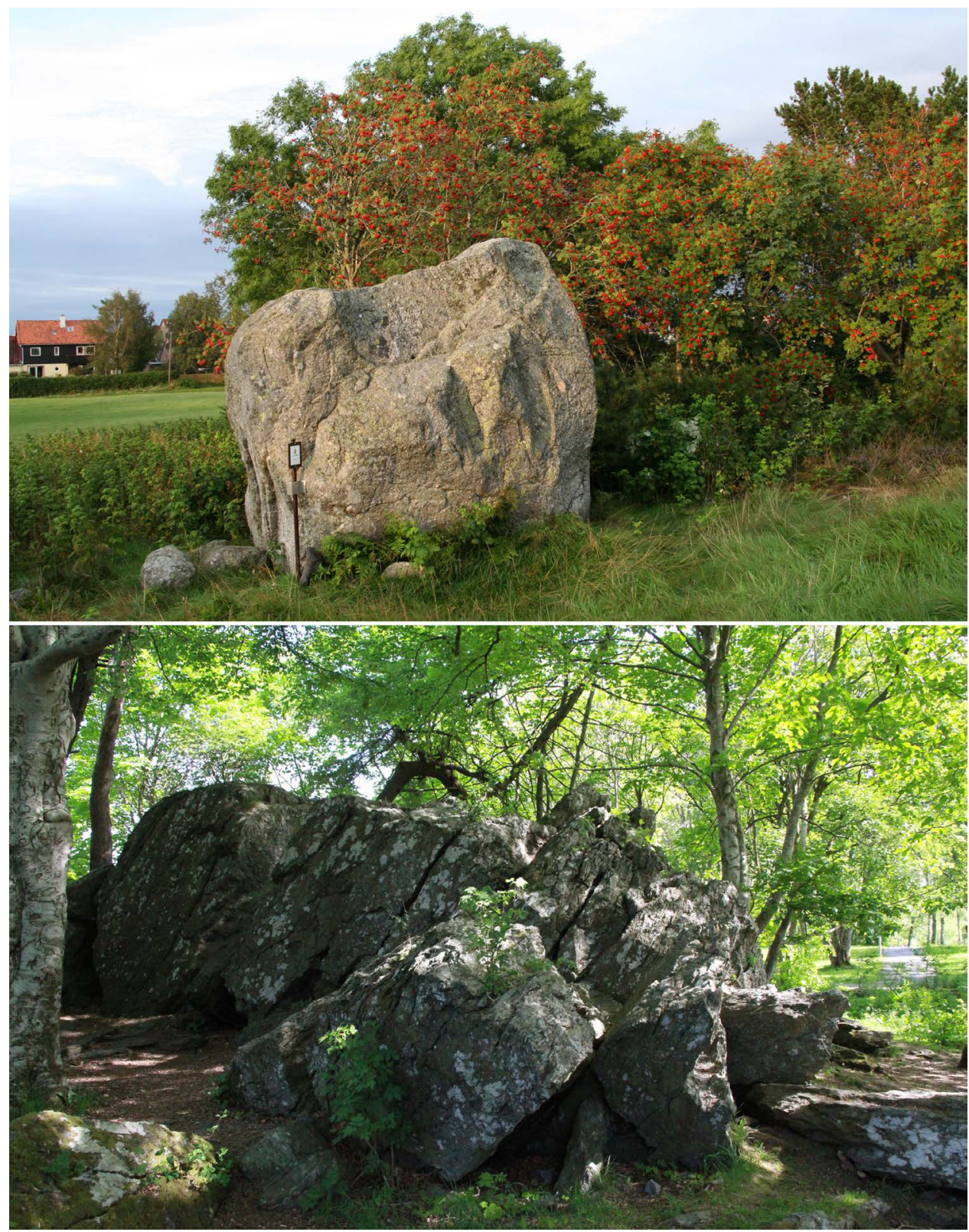

Figur 7: Øverst Kutmandssteinen på Byhaugen og nederst Klovsteinen bak Hjaltlandsgata 26. Begge er nevnt som grensesteiner for Eiganes i $1755 \mathrm{og}$ 1835. Kutmandssteinen ble vernet i 1959. Foto Kutmandssteinen: Arne Østensen, og Klovsteinen: Ragnhild Dreyer. 
(2) «Kløfstenen» er vår andre merkestein i grensen i vest (figur 7). Klovsteinen er bevart og ligger like nord for Hjaltlandsgaten 26. Den er kløyvd i flere deler, som navnet sier. Også den er angitt uten navn på kartet fra 1830. Derfra gikk grensen over midten av et nes midt på Mosvatnets nordvestre side. Terrenget ved Mosvatnet er forandret i nyere tid, men kartet fra 1830 viser et steingjerde som delte neset i to på midten.

(3) Grensen krysset Mosvatnet til Hillevågsbekken til den tredje grensesteinen. Hillevågsbekken het tidligere «Salleråen» og rant over Bekkefaret til Hillevåg. I 1686 kunne daværende eier av gården Ullandhaug, Maren, enke etter Peder Saxse, fremvise en stein som sto midt i bekken. Den var det rette delet mellom Eiganes, Ullandhaug og Lagård. Hvor langt ned i bekken den sto, vet vi ikke. Uansett nøyaktig grenselinje viser dette tydelig at Eiganes hadde eiendom på østsiden av Mosvatnet.

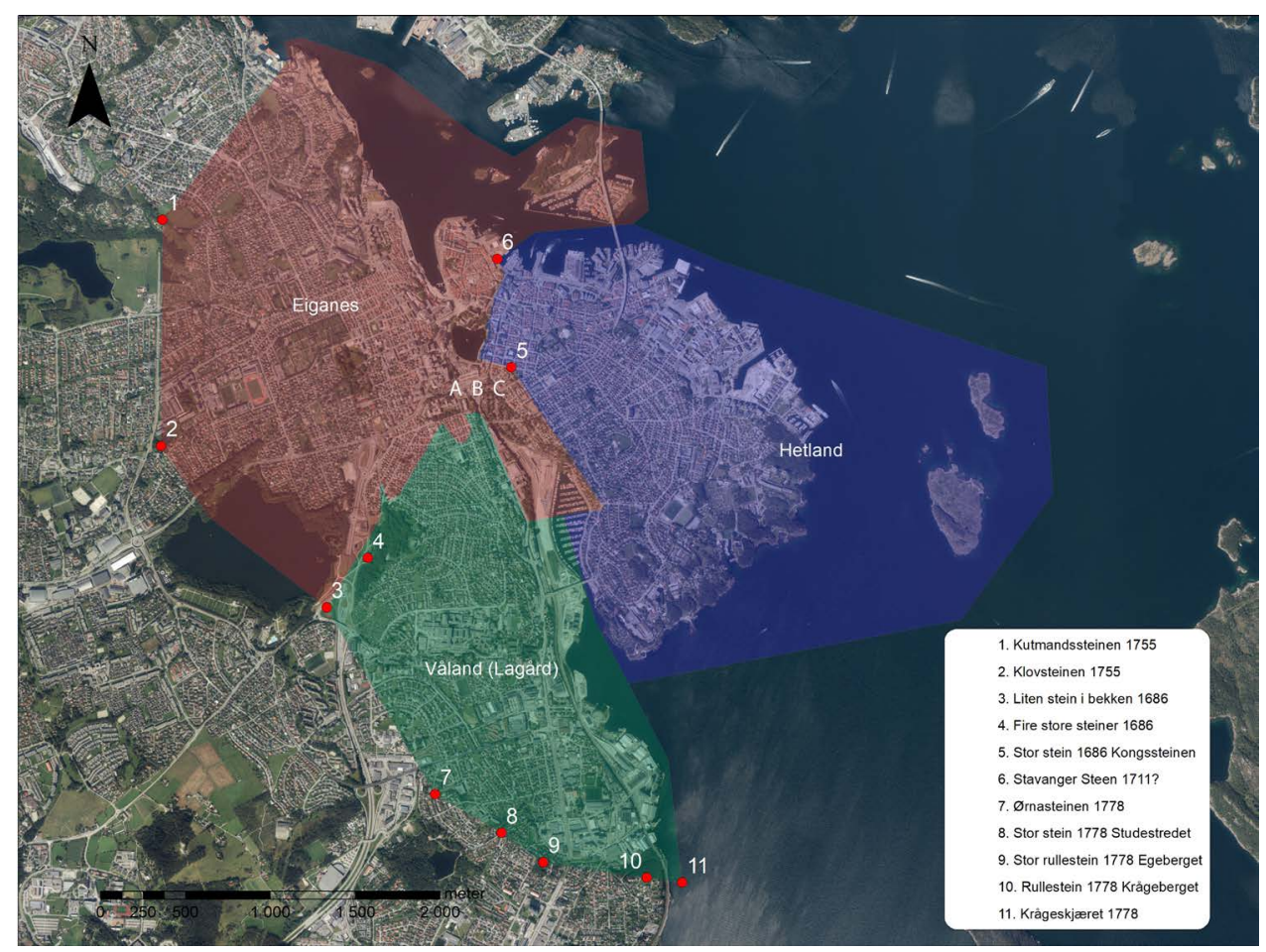

Figur 8: Kjente stavsteiner og forslag til gårdsgrenser omkring Stavanger før byen gradvis ble til på 900- og 1000-tallet. Grensesteinene er nevnt i merkegangsforretninger på 1600- og 1700-tallet. Det er usikkert om «Stavanger Steen» var et grensemerke. De fire steinene på Våland er plassert etter store steiner på et kart fra 1957, men identifikasjonen er usikker. En «plass» sør for Breiavatnet (vest for nr. 5, Kongssteinen) ble gitt i gave til kannikene og biskopen av en stormann i 1322. (A) Den vestre delen ble kalt Kanniket. (B) Den midtre biskopsparten av Eiganes smeltet sammen med biskopens «Ladegård», trolig et nytt navn på Våland. (C) Den østre parten ble hetende Eiganes, og lå antakelig til sognepresten i Mariakirken som også var kannik. Illustrasjon: Frode Iversen. 
(4) Fra steinen i Hillevågsbekken gikk grensen i 1686 til de «fiire store steene» ved Vålandshaugen som skulle være det rette delet og skiftet mellom Eiganes og Lagård. Lokalhistoriker Anders Bærheim (1959) plasserte de fire store steinene sør og litt vest for Vålandshaugen. Det finnes imidlertid flere alternativer. I lia her ligger flere flyttblokker mellom 45 til 60 moh. ${ }^{14} \mathrm{Jeg}$ har angitt et forslag på figur 8 etter en ansamling med steiner på «ØK-kartet» fra 1957. På 1830-kartet er det for øvrig inntegnet en stor geil ut fra «Vaalands Mark», som var Lagårds hovedbeite. Derfra gikk grensen til et punkt på daværende Løkkevei (nå Peder Klows gate) omtrent ved inngangen til Arkeologisk museum (kartene fra $1830 \mathrm{og}$ 1882). Herfra gikk grensen trolig langs tidligere Løkkeveien (nå Peder Klows gate) til Lagårdskleivå. Der kommer vi til det vanskelige området og vår femte og siste grensestein (figurene 9 og 10).

(5) I 1686 var det uenighet om grensene i området ved Lagård gravlund. På den ene siden sto byskriver Cort Høyer og byens borgerskap. På den andre siden den nye amtmann og eier av Lagård. Bispelagårds utmark strakte seg på ingen måte så langt inn på byens grunn som amtmannen hevdet, mente byens representanter. I beskrivelsen fra 1686 nevnes nå en Eiganes øde tilhørende byens grunn. Sognepresten på Hetland magister Jens Godtzen (1637-1713), anviste grensen nøyaktig. Opplysningene er viktige både fordi de viser at området ved Paradis tidligere het Eiganes, og at en stor stein dannet ødegårdens grense mot Hetland. Navnet Eiganes i dette området ledet lokalhistoriker Bærheim (1959) til å tro at Eiganes måtte være et navn på en gammel storgård som omfattet både Eiganes og Hetland. Som Helle (1975:45) har påpekt, smeltet Hetland og ødegården senere sammen, men dette var et ungt forhold. Vi skal se nærmere på detaljene i dette området.

I «Stauvangers dombkierckes» jordebok fra ca. 1620 nevnes Eiganes øde og Hetland sammen (Hodne 1986:51). Jordeboka viser inntektene til sognepresten i Domkirken, deriblant fra «Eikanes prebende». Prebendet omfattet «Hettland strax wden for byen» og «Ekannes øde herunder» i tillegg til andre gårder. Et prebende var en inntekt som lå til et bestemt alter eller en stol i koret i Domkirken i middelalderen (Kolsrud 1925).

I 1686 fremgår det at Eiganes øde omfattet et større område enn bare Paradis. Sognepresten forklarte at grensen gikk på et berg ovenfor Lagårds åker og eng. Der fulgte grensen et steingjerde som gikk ut fra en stor stein. Det fremgår at berget støtte mot Hetland, og slik kan være identisk med Risberget (Bærheim 1959:88-89). Vi får vite at ødegårdens grunn startet ved en stor stein som lå «noen favner» fra bergfallet ( 1 favn $=3$ alen $=1,88 \mathrm{~m}$ ). Derfra fulgte grensen bergfallet og gikk ned i Lagårds utmark ved enden av en åker som gikk ned til Hillevågsvannet. Denne åkeren lå utenfor Lagårds eng og åker (Bærheim 1959:88-89). Beskrivelsen er noe vanskelig å tolke, men grenselinjen synes å ha gått som følger: fra en stor stein nærmest byen $\rightarrow i$ en rett linje fra steingjerdets hjørne tett ved bergfallet $\rightarrow i$ en snorrett linje til en grensepæl ved et epletre $\rightarrow$ derfra i rett linje langs en slåttekant i bakken ovenfor i sør $\rightarrow$ ned i Lagårds utmark (Marsch) $\rightarrow$ og til enden av en åker som gikk ned til Hillevågsvannet, og som lå utenfor Lagårds åker og eng. Det er ingen tvil om at Eiganes' grunn startet ved en stor stein som lå i retning mot byen.

I dette området er det ikke kjent andre store steiner enn Kongssteinen som kan passe med beskrivelsen i 1686. De må derfor være identiske. På kart over Hetlandsmarka fra 1843 forstår vi de ulike elementene i området bedre enn på det yngre bykartet (figur 10). Den Hetland prestegård som er inntegnet på bykartet fra 1863-1866, var i mellomtiden ny (figur 9). Det var også Stiftelsesgata. Kartet fra 1843 stemmer derimot bra med beskrivelsen 


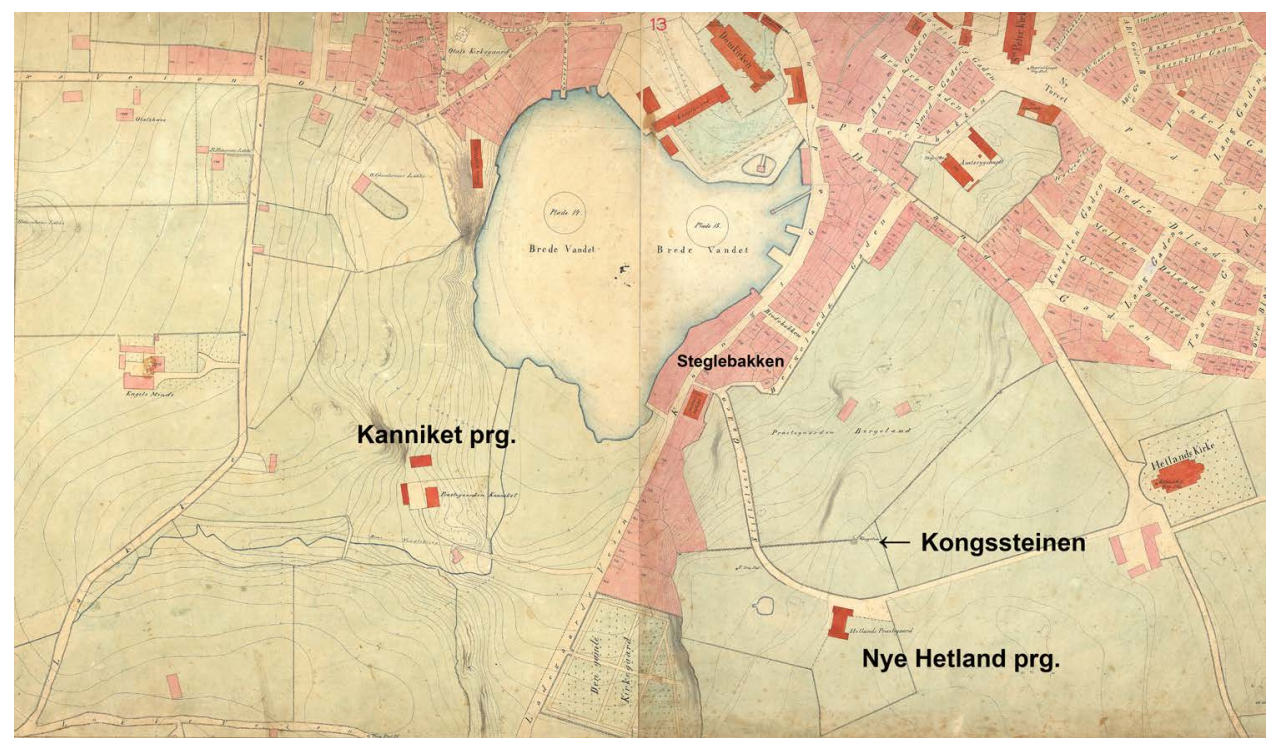

Figur 9: Utsnitt av kaptein Torstrups bykart for Stavanger, oppmålt i 1863-66. Kartet viser blant annet prestegårdene Kanniket og Hetland, og bygrensen ved Kongssteinen fra 1848 til 1878. Lagård fikk i middelalderen trolig lagt til et stykke eiendom ned til Breiavatnet mellom ødegården Eiganes og Kanniket. En stor stein som er nevnt som grensemerke for Eiganes øde i 1686, må helst vare identisk med Kongssteinen. Området for Steglebakken er avmerket etter Noess 2009. Stavanger byarkiv.

i 1686. I 1843 het området Ruden og Kilen. De lå i naturlig forlengelse av Paradis, og må helst ha tilhørt Eiganes øde i 1686. Senere ble Ruden bygslet bort fra Bergeland under Hetland (Simonsen 1972:58), og noe uklarhet om grensene er det her. Vi kan likevel konkludere med at Kongssteinen etter alt å dømme var grensestein for Eiganes gård mot Hetland.

Det fremgår i 1686 at Eiganes øde også omfattet Paradis, som gikk sør til Frue Terrasse, og som grenset mot Hetlandsmarka om lag ved den buktede Pølsesvingen. Eiganes øde hadde da grense så langt sør at det vokser frem en mistanke om at Våland (senere Lagård) en gang kan ha blitt skilt ut fra en større Eiganes gård. I alle fall omsluttet Eiganes i historisk tid Vålands nordre halvdel i linje fra Pølsesvingen til steinen i Hillevågsbekken. I så fall kan grensesteinene som nevnes i 1686 og 1778 mellom Lagård (= Våland) og Auglend i sør usikkert være en eldre grenselinje for et eldre «Stor-Eiganes» med Våland. I 1686 nevnes det to grensesteiner mellom Lagård (tidligere Våland) og Auglend: en «Liden stenhoug» og «en Steen». I 1778 får vi en detaljert beskrivelse av grenselinjen med følgende stavsteiner: «Ørnesteenen» $\rightarrow$ og «En Stor Steen på Studestredet, wed Landeveien» $\rightarrow$ «En Rundagtig Steen Stor hwidgraae» (På Egebacken) (nær grensen) $\rightarrow$ «En Stor Steen Rulle» $\rightarrow$ «Kraage Berget hvor der er en gammel Steen Rulle» $\rightarrow$ til «Kraage Skieeret i Gande Fjorden». ${ }^{15}$ Selv om en slik eldre grense for et «Stor-Eiganes» er høyst hypotetisk, viser dette likevel en lokal tradisjon på Jæren for nettopp å benytte store, naturlig lagte steiner som punkter i siktlinjer for å definere gårdsvaldene (se også Bærheim 1953). 

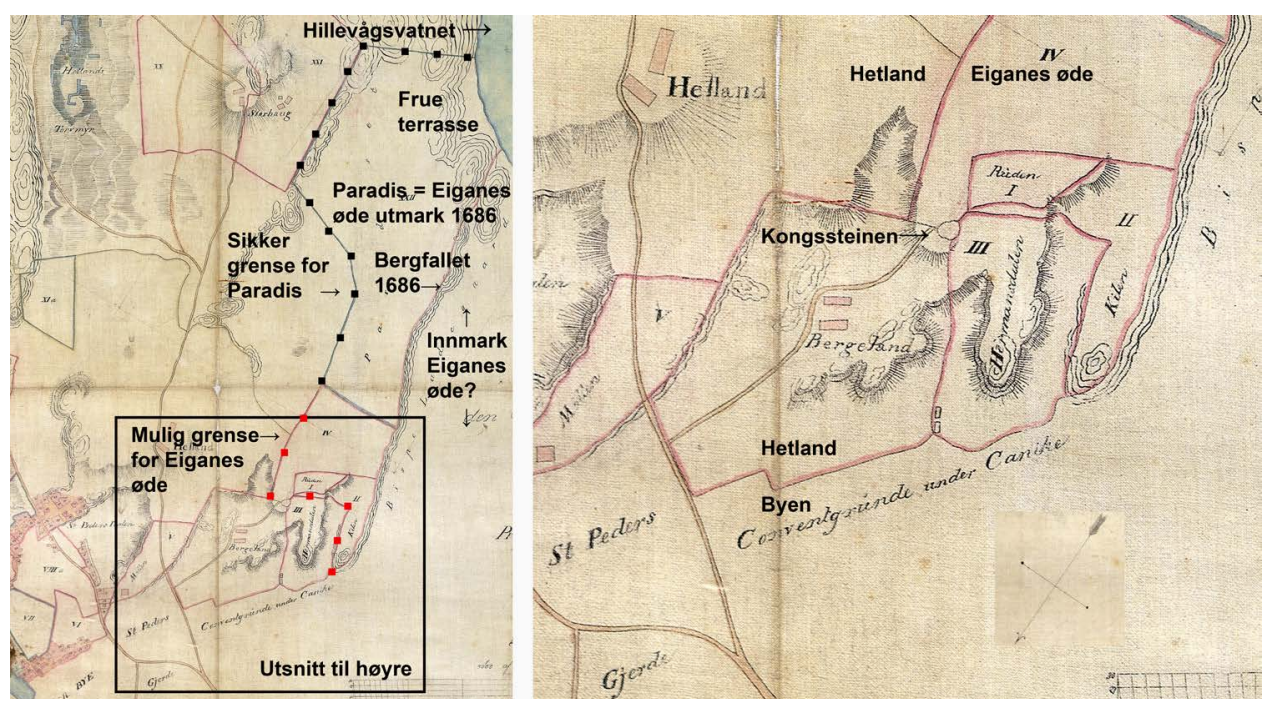

Figur 10: Utsnitt av kart over Hetlandsmarka fra 1843, orientert SØ med inntegnet forslag til østgrense for Eiganes øde mot Hetland. Kongssteinen er avmerket og fremdeles hel i 1843. Nye Hetland prestegård og Stiftelsesgata var ennå ikke oppført. Steingjerdet for Eiganes øde, som er nevnt i 1686, kan vare identisk med gjerdet mellom Ruden I og Kilen II, eventuelt mellom Kilen II og Hermandsdalen III, som kanskje gir en mer naturlig linje i terrenget. I 1686 heter det at ødegården Eiganes'grunn startet ved en stor stein, og $i 1726$ fremgår det at Kongssteinen lå noen favner (= noen meter) fra et bergfall. På kartet ser vi et bratt fall «nedenfor» Kongssteinen (egentlig mot vest). Kongssteinen er den eneste store steinen som er kjent $i$ området. Vi vet at ødegården 11686 omfattet mer enn bare Paradis. På kartet til venstre er det antydet en mulig innmark for Eiganes øde ved nåvaerende Lagård gravlund. Stavanger byarkiv.

Vi vet ikke sikkert hvor innmarken til Eiganes øde lå. I realiteten er det ikke så mange alternativer. Kvartærgeolog Asbjørn Simonsen har i en årrekke arbeidet med den historiske landskapsbruken omkring Breiavatnet. På hans kart over de beste dyrkingsområdene synes to områder å være særlig aktuelle for vårt Eiganes (Simonsen 2013:13): området for Lagård gravlund og området for nye Hetland prestegård. Bare her ville det være nok naturlige løsmasser til en skikkelig innmark. Lagård gravlund er kanskje mest sannsynlig, i alle fall fremgår det at området ved Kongssteinen var utmark i 1686. Et eventuelt tun for Eiganes øde ville ha ligget godt på bakketoppen mellom Breiavatnet og Hillevågsvatnet ca. 15 moh. Gården ville hatt fin, slak innmark på begge sider av tunet og utmark på berghyllen i øst. Gården hadde trolig båtstø ved Hillevågsvatnet, der et gammelt naust nevnes i 1686.

I stedet for å søke opphavet til Eiganes mot Hetland, slik Bærheim gjorde, er det mer naturlig å se nordvestover mot Eiganes bydel. Også Helle (1975:45) kom frem til at ødegården lå mellom Hetland og Bispelagård, som må være riktig. Siden begge områdene het Eiganes på 1600-tallet, er det nærliggende å tro at de en gang utgjorde ett samlet gårdsterritorium. Med andre ord var Eiganes øde, som ble liggende øde etter svartedauden, en part 


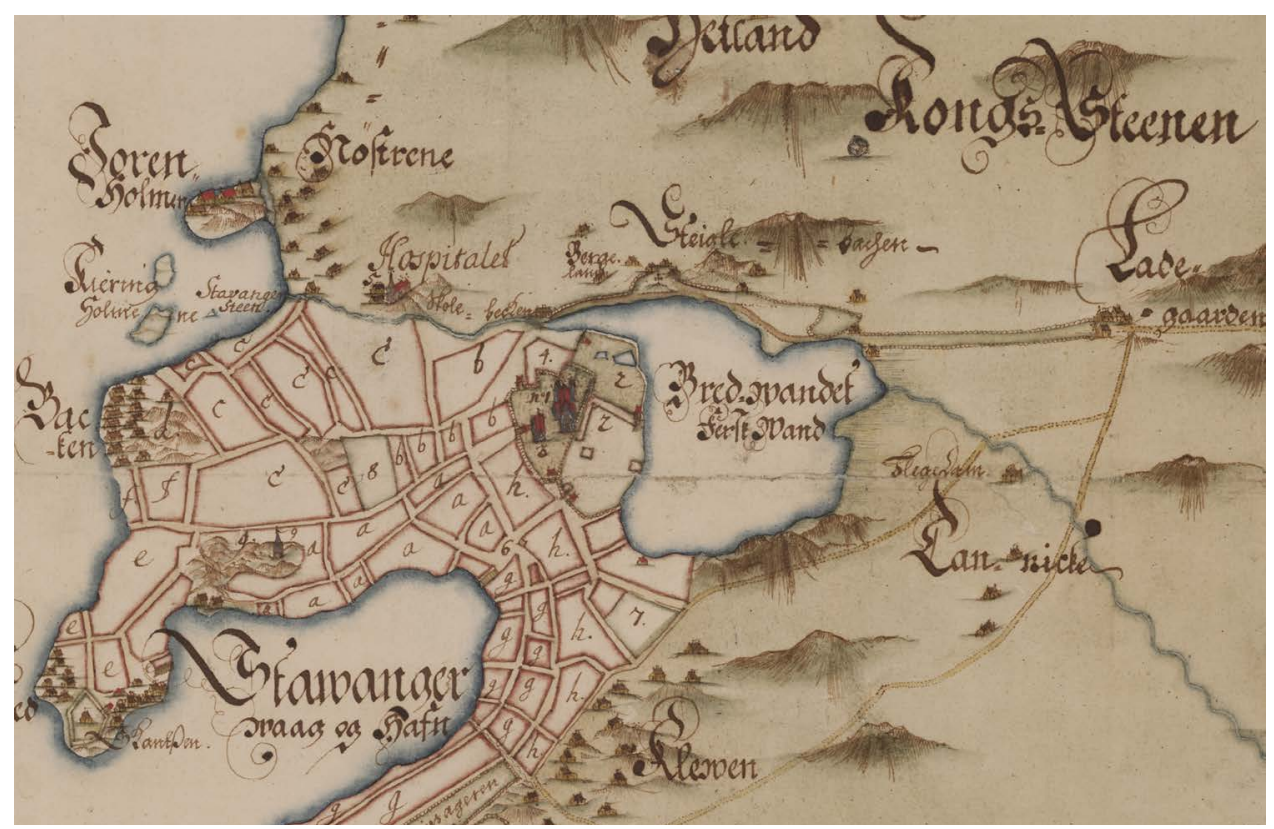

Figur 11: Utsnitt av Aagaards kart fra 1726. Lagårds eiendom strakte seg i en korridor ned til Breiavatnet. Skjceret «Stavanger Steen» til venstre. Aagaard har vort beskrevet som «en middelmådig kartograf, men fortrinlig kartkopist», og proporsjonen i kartet er unøyaktig. «Kongssteenen» er inntegnet $i$ øvre del av utsnittet, til høyre for midten. Også byens gamle rettersted Steglebakken øst for Breiavatnet er inntegnet sammen med Erling Skjalgsson-korset, som amtmann de Fine i 1743 opplyser var lokalisert der. Breiavatnet er benevnt som «Perlevand». Perlefangst var et kongelig privilegium. Det Kongelige Bibliotek, København.

av storgården Eiganes. De var adskilt av to eiendommer: et stykke av Lagård på hver side av den nåværende Kongsgata dannet en kil fra Lagårdskleivå til Breiavatnet, og dessuten Kanniket, som strakte seg vestover til Løkkeveien og nordover til Eiganesveien (figur 11).

Det er sannsynlig at Lagårds kile fra Lagårdskleivå til Breiavatnet var kommet til sekundært. Kilen delte territoriet for en eldre Eiganes i to. Gårdsgrensen følger ikke noe naturlig løp her, men danner et belte på begge siden av veien til byen. Vi kan også merke oss det provisoriske grensemerket som nevnes her i 1686 - en pæle slått ned ved siden av et epletre, ikke en solid gammel stein. Kanskje ble dette stykket lagt til Våland da biskopen gjorde den til ladegård. Lagård dukker dessverre først opp i skriftlige kilder i 1570-årene, og vi vet lite om den i middelalderen. ${ }^{16}$ Det må likevel ha vært en betydelig mengde naturalia som skulle lagres der. Biskopen tok en fjerdedel av tienden i stiftet. Tienden utgjorde ca. 10 prosent av produksjonen til gårdene. På 1800-tallet var det 9135 gårder i det tidligere stiftsområdet. ${ }^{17}$ I tillegg fikk biskopen landskyld fra eget jordegods og dessuten betydelige bøteinntekter. Lagårds lagre må derfor ha vært fulle i middelalderen, og fri passasje til byens havn kan ha vært viktig med tanke på transport, salg og utførsel av varer. 
(6) Avslutningsvis tar vi også med Stavanger Steen, som mer usikkert kan ha vært et grensemerke. Fra Kongssteinen fulgte bygrensen St. Peders gjerde og siden Skolebekken, som rant fra Breiavatnet til Østervåg. Ved Skolebekkens utløp lå «Stavanger Steen» - et skjær som er avmerket på Aagaards kart fra 1626, og som er ett av to skjær som er innmurt i Stenkarkaien (Thorson 1952:212). I oversettelsen av Torfæus heter det at navnet Stavanger «... kommer fra skjæret som ligger i nærheten, som er kalt Stav, og ordet anger, som er et gammel ord for hav» (Torfæus 2008 [1711]:171). Men trolig er dette en feilaktig oversettelse. ${ }^{18}$ Klokker Hans Smidt opplyser omkring 1770 at flo sjø gikk over skjæret som «kaldes almindelig Stavanger» (Erichsen 1906:44). Det må derfor nærmest ha vært et «skvalpeskjær». En ny studie av strandforskyvningen på Bokn viser at landet har hevet seg ca. $2 \mathrm{~m}$ de siste 2000 år (Johnsen 2017:87). Det er derfor tvilsomt om en eventuell funksjon som grensemerke kan være særlig gammel.

For å oppsummere var Kongssteinen én av flere grensesteiner for en eldre Eiganes gård. På 1300-tallet besto Eiganes trolig av en *nordre (eller vestre) og en *søndre (eller østre) del. ${ }^{19}$ Begge er omtalt som «plasser» (i 1322 og 1607). *Søndre Eiganes var sannsynligvis identisk med en «plaz» som kannikene fikk i 1322 for årtidhold i St. Svithun kirke for en stormann og familie (DN III nr. 132). *Nordre Eiganes var identisk med «en plads» som kongen ga byen i 1607 . Det kan tyde på at gården hadde to bruk. Vi må tro at 1322-gaven ble delt mellom biskop og kanniker siden årtidholdet skulle finne sted i biskopskirken. Det kan stemme med de senere eiendomsforholdene i området. Da var *søndre Eiganes delt mellom (A) kannikene (Kanniket), (B) biskopen (kilen fra Lagårdskleivå til Breiavatnet) og (C) sognepresten (Eiganes øde) (jf. A-B-C på figur 8). Det gamle navnet Eiganes ble hengende fast på den delen som grenset mot Hetland, og som sognepresten benyttet. ${ }^{20}$ Biskopens part av * søndre Eiganes kan ha smeltet sammen med Våland da den ble omgjort til ladegård. Denne gjennomgangen viser uansett at Kongssteinen sto i grensen mellom Hetland og Eiganes. Vi skal nå undersøke gårdene og landskapet i området da navnet Stavanger ble til i jernalderen.

\section{Landskap og gårder omkring Breiavatnet}

Vi ser nærmere på arkeologiske og vegetasjonshistoriske spor og undersøkelser i området omkring Breiavatnet. Gårdsvaldene på Jæren er tradisjonelt store og vide. Omkring Stavanger er det bare plass til tre større gårdsvald: Eiganes, Hetland og Våland (Lagård). ${ }^{21}$ Gårdsvaldet for Bergeland er for smått til å være en ordentlig gammel jærgård. Jeg regner den som en ung plass under Hetland. Skriftlige kilder til gårdenes historie finnes knapt, og det arkeologiske materialet er tynt.

Landskapet og vegetasjonsutviklingen omkring Breiavatnet og Vågen kan rekonstrueres 5000 år bakover i tid ved hjelp av Asbjørn Simonsens (1971) undersøkelser av pollen og sporer i sedimenter i Breiavatnet, publisert sist i 2013. Det er spor etter åker- og særlig beitebruk i den eldste perioden. Det store skiftet inntraff imidlertid først «... noen få hundre år etter Kristi fødsel» (Simonsen 2013:11). En intens nydyrking tok nå til, og skogen ble ryddet. I sedimentene forekommer det relativt sett store mengder kornpollen av havre. Det er forenlig med at det ble etablert en gård med kornåker i nærheten.

Det er stagnasjon i gårdsdriften på 700-800-tallet. Den kan stemme med den store tilbakegangen som sees mange andre steder i Norge og Skandinavia i perioden fra 536 til 750 
(Iversen 2017; Gundersen 2019). I vikingtid (800-1050) tok åkerbruket seg kraftig opp igjen omkring Breiavatnet. Nå ble det dyrket bygg i tillegg til havre, og også litt rug. Det intense åkerbruket avtar omkring 1300 .

I sum har Simonsen demonstrert at det var et mer eller mindre åpent jordbrukslandskap omkring Breiavatnet i yngre romertid og folkevandringstid (200-575 e.Kr.). Det ble etterfulgt av en periode med gjengroing før ny ekspansjon tok til i vikingtid. Det er altså god grunn til å anta at landskapet var åpent og fritt for skog da Stavanger-navnet ble dannet i eldre jernalder. Det er et viktig premiss for den videre «visuelle analysen» av hvorfra Kongssteinen kunne sees.

Språkforskeren Magnus Olsen (1926) undersøkte som den første såkalte -land-gårder mer systematisk, altså gårdsnavn med suffikset -land, slike som i Våland og Hetland. Hans kjente eksempel var Seim i Lindås. Der fant Olsen mellom åtte og ti -land-navn omkring en gammel kongsgård, hvorav sju var selvstendige gårder. Olsen hevdet at de «ringere» -landgårdene var utskilt fra Seim og representerte et underordnet jordegods (Olsen 1926:129). Olsen mente at -land-gårder ble etablert i perioden 400-800. Nå vokste det frem jordegods underordnet storgårder (se også Iversen 2008:206). Stedsnavngransker Inge Særheim har i sin doktorgrad fra 1999 studert -land-navn grundigere. Han finner at -land-elementet, i betydningen «tilleggsmark», «det som hører gården til», kan ha vært produktivt alt fra 200-tallet (Særheim 1999:260, 346).

For Våland gir arkeologien enkelte holdepunkter for gårdens alder, eller rettere sagt dyrkingsaktiviteten der. Førsteleddet er trolig gammelnorsk vá (vrá), for «krok, utkant» (Helle 1975:41). I 2017 undersøkte Arkeologisk museum i Stavanger et lite område i Agent Kiellands gate 27 sentralt på Våland (ID 221696). Det ble identifisert én kokegrop og, viktigere, også et $20 \mathrm{~cm}$ tykt fossilt åkerlag fra førromersk jernalder. Kokegropen var gravd ned i åkeren i romertid (Eilertsen 2017). Det viser dyrking allerede tidligere enn Særheims generelle dateringsforslag for -land-navn. Men vi kan ikke vite sikkert om de arkeologiske sporene stammer fra en gård som da het Våland. Enkelte løsfunn fra Våland peker mot aktivitet $\mathrm{i}$ jernalderen (Eilertsen 2017). På Hetland (av hesli $\mathrm{n}$. = «hassel») er det lite arkeologi annet enn den velkjente storhaugen på Storhaug (ID 44497) og to gravhauger som konservator Tor Helliesen (1900:43-44) ved Stavanger museum registrerte ved Ramsvig og Digranes mot Gandsfjorden. Gravene ligger langt unna aktuelle bosetningsområder på Hetland, og har derfor liten utsagnskraft for gårdens spesifikke historie. Storhaugen på Storhaug er fra bronsealderen, og funn av en praktspenne av forgylt bronse fra 700-tallet stammer trolig fra en sekundærgrav.

Den arkeologiske stoda er ikke nevneverdig bedre for Eiganes. På Aagaards kart fra 1726 er tuftene for et gammelt tun på Eiganes unøyaktig angitt $i$ form av et omriss av to bygninger «hvor Tompten endnu vises». De er plassert et stykke nord for «Varlandshougen» (Vålandshaugen), men proporsjonene i kartet er ikke til å stole på. Vi kan gjette på at en bautastein som arkeolog Oddmund Møllerop fant liggende i nærheten av krematoriet ved Eiganes kirkegård i 1948, indikerer stedet for et eldre tun (ID 15294). Det kan stemme med opplysningene hos klokker Smidt fra ca. 1770. Han nevner at en del byhus står oppå bakken over «Kleven» «hvor Egenesmarken begynder, hvor forhen har været en bondegaard» (Erichsen 1906:57).

Det har vært diskutert om det lå et eldre tun ved Domkirken ved Breiavatnet. Særlig arkeologen Arnvid Lillehammer (2000) har tenkt seg det. Den eldste bybebyggelsen lå 
i innerste del av Vågen og mot Østervåg. Mulig eldre keramikk og kulturlag under Domkirkens kor og Erling Skjalgsson-korset viste aktivitet på stedet før ca. 1100. Lillehammer fremholdt: «sett i høve til jordbrukspotensialet er ryggen mellom Vågen og Breiavatnet ein naturleg stad for eit eldre gardstun» (Lillehammer 2000:19).

Lillehammers resultater er i nyere tid drøftet mer inngående av arkeologene Jan Brendalsmo og Knut Paasche (2017) i lys av NIKUs utgravinger i Stavanger 2004-2014. Deres arbeid ble publisert etter Ersland og Sollis byhistorie. Brendalsmo og Paasche (2017:103) konkluderer med «at gården Stavanger i vikingtid og på 1000-tallet med stor sannsynlighet kan karakteriseres som et anløps- og utvekslingssted med flere sentrumsfunksjoner».

Arkeologiske spor nær Domkirken (Haakon VIIs gate) viser to bruksfaser alt i folkevandringstid. Det dreier seg om hardpakket grus og småstein, som likevel ikke tillegges stor vekt da det er uklart hva det representerer. Det mangler kulturlag fra merovingertid, men små lommer av det dukker opp i vikingtid. Særlig mellom 950 og 1150 er funnene tydelige. Det dreier seg om bygningsrester, stier, små avfallshauger og husholdningsavfall som brente og ubrente bein. Det er funnet spinnehjul, vevlodd, bryne, fiskekroker og skår av kleberkar, men også spor av metallhåndverk (støpeformfragmenter). Seks ildsteder på og over påviste golv er datert til vikingtid og inn på 1100-tallet. Det er ikke usannsynlig at funnene kan stamme fra en tidlig markedsplass, kanskje etablert omkring 950, eller, kanskje noe mindre sannsynlig, et gårdsanlegg. Det er for øvrig ikke funnet spor etter produksjon av eikestaver og skipsplank, som lokalhistoriker Finn Bringsfjord (2009) mente Stavangernavnet kunne ha sammenheng med.

Det er funnet en handelsindikerende skålvekt i kulturlag under Domkirken. Den kan stamme fra en vikingtidsgrav i området, og i utfyllingene i Vågen er det gjort funn av nåler fra ringspenner fra vikingtiden (Lillehammer 2000:18). Dette tyder på at det lå én eller flere hedenske graver på høyden for Domkirken (Brendalsmo og Paasche 2019:112). En runestein i Mariakirkens fundament viser en tidlig kristen grav og harmonerer med nye C14dateringer av elleve kristne graver under den romanske krypten i domkirkens gotiske kor, der de eldste må være fra 900-tallet (Denham 2014). Kanskje lå det et lite vikingtidsgravfelt på høyden ved den gamle hovedveien fra Jæren til den lune havnen i Østervåg. På grunn av ferdsel og sentral beliggenhet i Rogaland vokste det frem en liten markedsplass her. Alt i Håkon den godes tid var det en kristen menighet og kirke i Stavanger, og stedet var trolig nært forbundet med den mektige Sola-slekten, slik en runeinnskrift på Stavanger-korset tyder på omkring 1050: «Alfgeirr prest reiste denne steinen etter Erling sin herre (som einsam vart sviken or aren) då han slost med Olav». Aslak Liestøl tolket i 1954 innskriften og korset skarpsindig, og etter mitt syn overbevisende, som et minne over Erling Skjalgsson på Sola, som ble drept i et sjøslag ved Bokn 21. desember 1028 (NiYR III:245-258). ${ }^{22}$ Dette «utvekslingsstedet» var kimen til byen Stavanger og neppe en vanlig gård.

Helle mente at Stavanger var utskilt fra en eldre gård Eiganes. Neset kunne være neset mellom Vågen og Østervåg. Vestre del ble kalt Skagen i middelalderen, som nettopp betyr nes eller odde (gammelnorsk skagi, nes, odde) (Helle 1975:49). Det er lite i skriftlige og arkeologiske kilder som kan hjelpe med nærmere tidfesting av Eiganes, heller ikke toponymet. Men analysen av pollen og sporer fra Breiavatnet viser som nevnt rydding for åkerbruk på 300-tallet. Det er usikkert om dette har sammenheng med etableringen av «bruket» Eiganes øde, eller mer sannsynlig en utskillelse av Hetland som egen gård. Bare fremtidige 
arkeologiske undersøkelser i byens mange «uforstyrrede» villahager vil kunne gi mer presis kunnskap om gårdene og eldre dyrking her, slik arkeolog Krister Eilertsen (2017) nylig har påpekt.

Vi kan konkludere med at Eiganes, Våland og Hetland kan være, og trolig er, gamle gårder, selv om de arkeologiske sporene er beskjedne. Det synes å ha blitt etablert enten en form for markedsplass eller spesialisert bebyggelse ved Domkirken senest på 900-tallet. Dette kan ha vært en forløper for byen Stavanger. Analyser av pollen fra Breiavatnet tyder på at det ble ryddet en gård i nærheten alt på 300-tallet. Det kan da dreie seg om Eiganes øde eller Hetland som begge lå nær Breiavatnet. Det er forenlig med perioden da Stavanger-navnet ble dannet. På den tiden ble det trolig nødvendig å definere gårdsgrensene i landskapet her.

\section{Stavanger-navnet i lys av stav- og stavsto-tradisjonen og Stavanger-navnene i Sunnfjord}

Norrønt stafr har ingen annen primær betydning enn «stav, stokk», eventuelt brukt om reisverk i bygninger eller om merkestaver i utmark, heller ikke etymologisk (Bjorvand og Lindeman 2007:1046). Det er denne betydningen som må ligge til grunn for tolkning av Stavanger-navnet. Vi skal da forvente noe langt/høyt, smalt og beint som referanse.

Ordet stav opptrer første gang på en runeinnskrift datert til 520/30-560/70 e.Kr. på den såkalte Gummarp-steinen i Blekinge (DR 358) (Imer 2015 [2007]). Der hører vi at «HaduwulfR satte tre staver fff» (Hapuwolafa[R] sate staba prią fff). Trolig viser staba her til de tre f-runene som er risset inn på D-siden (Düwel 1983:33), og ikke for eksempel grensemerker i området. Stav opptrer også på runeinnskrifter fra vikingtiden. Ordet refererer da til runer, datidens «bokstaver», i formelen «NN reiste stav og stein etter NN», eller liknende (Marstrander 1953:155).

Ordet må likevel tidlig ha fått appellativisk betydning for de ytterste grensemerkene på en gård. Lovspråk er gjerne konservativt, og det er som grensemerke vi møter ordet stav i Frostatingsloven ca. 1260 i utrykkene innan stafs og utan stafs (NgL I:125 ${ }^{19}, 244^{13}$; Heggstad mfl. 1975:4074). Andre norrøne ord for merkesteiner i Skandinavia var for eksempel lýritti, marksteinn, rör, hreysar og ticeldru sten (Love mfl. (red.) 2020:538-539).

I Rogaland og Agder forekommer stavsto- og stabbnavn på grensepunkter (Hovstad 1980:42-47). Tradisjonen er dokumentert i en rekke diplomer fra middelalderen. ${ }^{23}$ Blant de eldste beleggene er et brev fra 1313 skrevet i Stavanger, som gjelder en gård i Nedstrand (Ryfylke). Gården omfattet også ollum lunnendom vttan gardz ok innan fiughura stafstoeða - alle luter i utmarken innen fire stavstoder (DN II nr. 115).

Stavstoene på Jæren er grundigst undersøkt av historiker Albert Myhre (1953). De var plassert der grensene for to, eller vanligere tre eller flere gårder støtte (stod) sammen (Myhre 1953:48). For eksempel nevner rettsdokumenter fra 1670-årene «... En Steen Som er Staff Stenen ...» mellom gårdene Njølstad, Garborg og Gausland i Time og Hå (Myhre 1953:51). Staven i stavstoen skulle være høy, høyere enn en vanlig skiftestein, eller «... vera merkeleg på anna vis», slik som den Raue hoen (rød?) eller Den skrevna hedlo (med streker på), eller rett og slett bare «... vera store steinar på godt synlege høgder» (Myhre 1953:46), slik som Kongssteinen.

Slike grensemerker føyer seg inn i en godt kjent tradisjon i Europa. De angelsaksiske såkalte boundary clauses i skjøter og brev fra 679 til 1066 e.Kr. danner interessante paral- 
leller. ${ }^{24}$ Det er nevnt 16000 - 18000 konkrete grensemerker i det engelske korpus (Kitson 1994). Hyppig forekommer steiner, såkalte «hoarstones», «grå steiner» (av AS hār, «grå»). ${ }^{25}$ I realiteten, men ikke etymologisk, tilsvarer dette vår hjemlige tradisjon med «hornsteina» / «hornstaver» (av norrønt hyrna, «hjørne»), «stavsto» og «endestav», som Håkon Hovstad (1980:42-54) har studert mer inngående.

Det usammensatte ordet staf i Stafangr kan ikke være en sammentrekning av det sammensatte dialektordet stavsto (leddet -sto ville neppe ha falt bort). Stavsto kommer av et mellomnorsk stafstóð, som henger sammen med norrønt stafstœði, «endepunkt av en grenselinje». Ordet må opprinnelig ha vist til faktiske merkestaver av tre eller i det minste høye og rette steiner som kunne sammenliknes med staver. Hovlands (1980) studie av diplomer fra middelalderen viser at stavsto ble brukt som appellativ, ofte i formelen «innen fire stavstoer».

Geografisk omfatter stavsto-området Ryfylke til Telemark. Ordene stavsto og stabb forekommer flere steder på moderne kart som konkrete punkter i grenser mellom gårder og eldre skipreider (nå kommuner). Hovstad anser disse som de eldste grensemerkene i et jordbrukslandskap. Tradisjonen forsvant på 1800-tallet da steingarder ble oppført mellom stavstoene (Hovstad 1980:45 med referanse til Albert Myhre). Siktlinjer ble erstattet av fysiske gjerder. Typisk står de gamle stavstoene nå i knekkpunkter i grensene (figur 12).

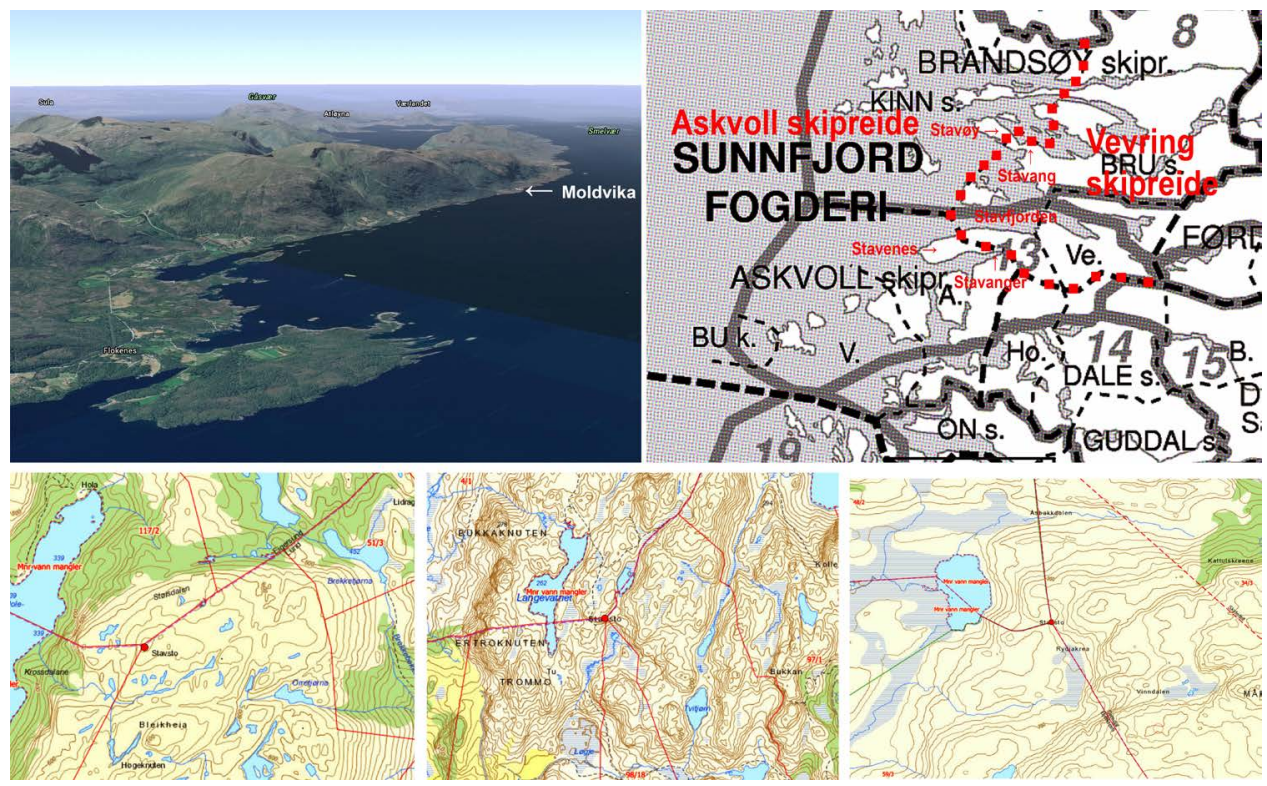

Figur 12: Stavenes i Sunnfjord og stavstoer i Rogaland. Øverst til venstre de karakteristiske fjelltoppene på Staveneset i Sunnfjord. Kanskje refererte *Stavane til de to fjelltoppene i grensen? En gammel skipreidegrense krysset neset fra Moldvika og fulgte toppene. Kartet øverst til høyre viser stedsnavn med stav som kanskje er forbundet med grensen. Tegnegrunnlag: utsnitt av kart av Jørgen H. Marthinsen. Kartene nede viser eksempler på stavstoer og grenser i Rogaland på moderne kart. Google Earth, Statens kartverk. Illustrasjon: Frode Iversen. 
Det er på det rene at steiner ble brukt som grensemerker. Studien «Gardsgrensene i Gyland» tar for seg 87 kjente grensemerker i en bygd med ca. 50 matrikkelgårder lengst vest i Vest-Agder (Eikeland 1957:120-128). I 63 av grensemerkene (72 prosent) inngår steiner av forskjellig slag, særlig «femsteiner» og røyser. Også i Gyland er det påvist store flyttblokker som grensemerker (nr. 32, 51, 53). Men som i Stavanger har heller ikke disse egennavn med «stav» eller «stavsto». De heter Sjøsteinen (sjøen er synlig fra den), Stordalssteinen og Hammersteinen. Hverken i Gyland eller i Stavanger-området finner vi stav eller stavsto som egennavn på grensemerker. Stavsto opptrer imidlertid sikkert som egennavn på grensemerker enkelte andre steder. Fire av fem eksempler på moderne kart finnes i Rogaland (Lund, Time, Bjerkreim og Sandnes), der de har klar sammenheng med matrikkelgårds- og nåværende kommunegrenser.

Stavanger-navnene i Sunnfjord har ikke vært vurdert i lys av grenser. ${ }^{26}$ Et viktig poeng for oss er at en eldre skipreidegrense krysset Stavenes - den karakteristiske halvøya i Firda (figur 12). Denne kan også ha vært grense mellom to av de fire såkalte fjerdingene, norrønt fjórðungr, som middelalderens Firdafylke var delt i (se Indrebø 1935:15). Det vil føre for langt å diskutere alderen på skipreidene og fjerdingene her. Jeg legger likevel til grunn at deres forløperne var rettskretser med røtter i jernalderen. Dette premisset finner støtte i nyere studier av ringtunene på vestkysten av Norge (ca. 100-1000 e.Kr.) (Iversen 2019; Semple mfl. 2020). Ringtunene blir nå tolket som sentrale tingsteder der bygdelagene hadde egne tingboder. For mange anlegg er det nettopp påvist et sammenfall mellom antallet boder og antallet skipreider innen fylker eller underinndelinger av fylker (fjerdinger). Det indikerer at de lokale kretsene (skipreidene) vi fanger opp i kilder i middelalderen, er langt eldre som rettskretser og kanskje minst like gamle som ringtunene. Jeg anser derfor slike grenser som relevante for diskusjonen av Stavanger-navnene i Sunnfjord fordi navnene og grensene kan være dannet samtidig.

Over Stavenes gikk det altså i 1520 en grense mellom skipreidene Askvoll i vest og Vevring i øst (Bull 1920:118, 121). Askvoll skipreide omfattet da Kinn sogn, nordvest for Stavenes, og Vevring skipreide Svanøy (Stavanger) sogn, nordøst ved Stavenes (Bull 1920:121). Dermed var det en vestre og en østre skipreide som tok hver sin del av Stavenes. Dette kan også ha vært grensen mellom «*Bru» og «*Askvoll» fjerdinger (Indrebø 1935:15). ${ }^{27}$ Grensen gikk slik at gårdene nordøst på Stavenes tilhørte Vereide, og gårdene i vest og sør Askvoll. ${ }^{28}$ Grensen fulgte de karakteristiske fjelltoppene Toreheia (717 moh.) og Ytrevågefjellet (667 moh.). Dette er ruvende topper og sjømerker godt synlige fra leia. Kanskje var det de egentlige * Stavane. ${ }^{29}$ Nordover gikk skipreidegrensen tversover Stavøya og svingte østover mot gården med navnet Stavang, som omfattet områder ved fjorden der grensen gikk. Det er nærliggende å tro at alle disse navnene har sammenheng med den gamle grensen, uten at vi skal drøfte dette i full dybde her. Vi har da den merkelige situasjonen at det ligger en Stavfjord nord for Stavaneset og en Stavanger (Stongfjorden) sør for Stavenes. Fjordene utgjorde ikke grenser i seg selv, men felles var god sikt til de antatte *Stavane på Stavenes.

Stedsnavngranskere har siden Rygh villet se bratte fjellskrenter og steile berg som grunnlag for bruken av stav i stedsnavn, også for Stavanger. I innledningen til Norske Gaardnavne skriver Rygh: «Det er brukt på fjeldnavn og på fremstikkende halvøer og nes som hadde en slik form at de kunne sammenliknes med en stav» (Rygh 1898:78). Det er en tung forskningstradisjon for å peke på Valberget (Skagen) som staven (Helle 1975; Holm 1991:82). 
I nyere tid har stedsnavngransker Inge Særheim sluttet seg til Valberget som stav. Han har presisert og nyansert dette nærmere til «... det rette neset på austsida av vågen, kalla Skagen ...» (=Valberget) (Særheim 2007:216). Særheim gjør dermed nesets rette form til et hovedpoeng. 3D-modellering av landskapet rundt Stavanger viser imidlertid at Skagen/Valberget ikke er en særskilt rett formasjon, snarere har det en mer avrundet form. En sentral stedsnavngransker som Ola Stemshaug (1985:70) holder en knapp på en variant av den andre klassiske tolkningen: «den beine vika» (altså Vågen). Dette understreker uenigheten blant ledende navnegranskere.

Det er et faktum at ingen filologer, eller for den saks skyld historikere eller andre, har vurdert Kongssteinen som navngivende for fjorden. Det er også et faktum at Stav-navnene i Sunnfjord tidligere ikke er blitt undersøkt i relasjon til eldre administrative grenser her, slik jeg har gjort ovenfor. Navn oppsto ikke i en «kulturløs topografi». Det er en svakhet ved den faghistoriske drøftingen av Stavanger-navnene. Kulturell kontekst făr for liten plass i vurderingene, og topografi vektlegges for sterkt. Jeg har vist at stedene med stav i førsteleddet i Sunnfjord opptrer i forbindelse med en grense som kan ha meget høy alder. Det er et viktig argument for min tolkning av Stavanger-navnet.

Minner så Kongssteinen om en stav? Formen på steinen er ikke enkel å rekonstruere nøyaktig på bakgrunn av 1726-målene og de få fotografiene som finnes. Smalsiden synes å ha vært vendt mot Vågen. Steinen tippet noe nedover i terrenget, og lå lavere $\mathrm{i}$ forkant enn bakkant. Fra Vågen ville den virke høyere enn bred. Visuelt fremsto den ikke som en slank, elegant stav. Den hadde likevel en mer stående, rektangulær form og en klarere «stav»-form enn både Valberget og Vågen. Men dersom den var navngivende for fjorden, må det ha vært funksjonen som grensemerke som var det primære. Den kan ha fungert som grensemerke i omkring 1000 år, frem til senmiddelalderen da Eiganes øde ble lagt øde. På 1600-tallet ble Eiganes øde brukt fra Hetland prestegård, og grensemerket mistet betydning.

Det er ca. $550 \mathrm{~m}$ mellom Kongssteinen og Vågen. Er det for langt unna til at Kongssteinen kan ha gitt navn til fjorden? Burde det navngivende elementet ha ligget nærmere? Vi kan sammenligne med den tidligere nevnte flyttblokken og grensemerket Sjøsteinen i Gyland. Fra Sjøsteinen ved Gråhei ved Mydland i Gyland var det utsyn til sjøen. Sjøutsikten må være bakgrunnen for navnedannelsen (Eikeland 1957:123, nr. 32). Situasjonen var dermed motsatt av den i Stavanger, der perspektivet var «fra fjorden til staven», mens i Gyland «fra steinen til sjøen». Fra Sjøsteinen er det nær $30 \mathrm{~km}$ til havet og $10 \mathrm{~km}$ til Lundevannet, som er de aktuelle «sjøene» i området. Da blir $550 \mathrm{~m}$ fra fjorden til staven i Stavanger småtteri. Kongssteinen var svært godt synlig fra Vågen, men også i farvannet omkring. Den var et grensemerke mellom gårder som kan ha blitt ryddet alt $i$ eldre jernalder. Poenget må være at ordet stav ble brukt appellativisk for grensemerke allerede da Stavanger-navnet ble til, $\mathrm{i}$ betydningen «fjorden ved grensemerket».

Torfæus hevdet i 1711 at Stav i Stavanger hadde sitt opphav i en peilestein, eller det han på latin omtalte som «scopulo». I autoritative latinske ordbøker oversettes det som nevnt med «projecting rock». En riktigere oversettelse av Torfæus blir da: «Navnet kommer fra peilesteinen som ligger i nærheten, som er kalt Stav, og ordet anger, som er et gammel ord for hav» (se Torfæi 1711:64 og Torfæus 2008 [1711]:171). Opplysningen hos Torfæus ble senere misforstått og knyttet til skjæret «Stavanger Steen» i Østervåg som er avmerket på Aagaards kart fra 1726. Men Torfæus siktet neppe til dette skjæret, slik Smidt og de Fine trodde. Opplysningene kommer i et annet lys når de knyttes til Kongssteinen i stedet for 
«Stavanger Steen». Det er ikke kjent hvilke kilder Torfæus baserte seg på, men sannsynligvis dreier det seg om muntlig tradisjon i området eller egne observasjoner og spekulasjoner.

For å vurdere rimeligheten i «siktargumentet» skal vi nå undersøke dette helt konkret. Fra hvor kunne Kongssteinen sees?

\section{«Visuell» analyse}

Vi skal nå undersøke i detalj hvorfra Kongssteinen var synlig i eldre jernalder. Landskapet var nå åpent og stort sett trefritt. Vi tar hensyn til vegetasjonshøyde og endret havnivå. Landskapet er rekonstruert fra LiDAR- og høydedata tilgjengelige via hoydedata.no. Vi har benyttet datasettet Rogaland 2014, 5 punkter per kvadratmeter. Bygninger og annet er da fjernet, slik at topografien blir gjenskapt med noenlunde nøyaktighet.

Bang-Andersen (2016:33) opplyser at Kongssteinen var 8,4 m høy og 8,7 m bred, men det kan ikke stemme. Fra Christie i 1828 har vi mål og proporsjoner i tre dimensjoner oppgitt i alen: 12 lengde, 10 bredde og 9 høyde. I 1824 ble alenmålet regulert til $62,75 \mathrm{~cm}, \mathrm{og}$ Christies mål tilsvarer ca. 7,5 x 6,2 m og høyden 5,6 m. Dette stemmer ganske bra med Aagaards mål (tabell 1). Dette er mål per flate oppgitt i sjællandske alen $(62,7707 \mathrm{~cm})$. Aagaards tegning er i realiteten en slags «3D-tegning» angitt i «2D», og ikke en avbildning av steinen som sådan.

Målene gir best mening dersom Aagaards «lengde» egentlig er et tverrmål eller følger flatenes kurver. Spesielt viktig er hans angivelse av vinkelrett høyde for flate 5, tilsvarende $5,65 \mathrm{~m}$ («Perpendicular Høyde paa same Østre kant»). Det må være steinens høyde i øst. Tilsvarende var «Perpendicular» høyde i vest 4,39 m (flate 7). ${ }^{30}$ Den søndre flaten var skjult av noe i 1708 (busker?), og mål foreligger ikke. Men Aagaard angir høyden i sør, målt «fra grunden», til tilsvarende $3,45 \mathrm{~m}$.

Aagaard angir også «tykkelse»: «Steenens Tyck-hed er tvert igiennem» 12 alen. Det tilsvarer 7,53 m lengde (N-S). Dermed stemmer Christies og Aagaards mål ganske bra. Med Christies ene tverrmål synes steinen da å ha hatt en diameter på 7,53 m N-S og 6,20 m Ø-V. og en høyde i øst på $5,65 \mathrm{~m}$.

Regnestykket til Bang-Andersen (2016) virker også noe raust når vi sammenlikner Kongssteinen med bygninger på eldre fotografier. Hovedbygningen på Hetland prestegård figurerer sammen med Kongssteinen, og ligger litt lenger unna nullpunktet i det eldste fotografiet. Den har en mønehøyde på nordre fløy på $9 \mathrm{~m}$ (mål fra hoydedata.no). Kongssteinen har ca. 70 prosent av denne mønehøyden. Det tilsvarer $6,3 \mathrm{~m}$. Med tanke på at steinen ligger litt nærmere i fotografiet, er dette forenlig med en høyde i øst på 5,65 m.

I lokal litteratur har tidsvitner beskrevet Kongssteinen slik: «Det lod sig gjøre at klyve op paa toppen av den, og der sad jeg nu for sidste gang og saa udover fjorden» (Giverholt 1899:84); «... den veldige steinblokken som lå og ruvet opp på høyden» og «Fra toppen der nøt en utsynet over byen» (Enoksen mfl. (red.) 1944:10); «For en severdighet», «Den var kulerund og stor som et lite hus», «Alle måtte jo ha vært oppå Kongssteinen» og «Det var godt stoff i den, hard, fin granitt» (Røys 1952:43). Ikke minst beskriver pastor Jens Marius Giverholt (1848-1916), venn av Alexander Kielland og modell til «Lille Marius» i Gift, Kongssteinen slik i sin erindring «Fra Skoledagene» fra 1899: Storstenen var en af disse mægtige rullestene, som jo skal være kommen rækende paa isen. Det saaes nu ialtfald 


\begin{tabular}{|l|l|l|l|l|l|l|l|}
\hline \multicolumn{2}{|l|}{ A 1726 } & \multicolumn{2}{l}{ B 1736 K } & \multicolumn{2}{l}{ C 1736 D } & \multicolumn{2}{l|}{ Mål omregnet } \\
\hline Flate & S. alen & Flate & S. alen & Flate & S. alen & Side & Meter \\
\hline 1 & 9,5 & 1 & 9,5 & 1 & 9,5 & Lengde sørside, tverrmål? & 5,96 \\
\hline 1 & 7,5 & 1 & 7,5 & 1 & 7,5 & Bredde sørside & 4,71 \\
\hline 2 & 11,5 & 2 & 11,5 & 2 & 11,5 & Lengde, nordside, tverrmål? & 7,22 \\
\hline 2 & 7,25 & 2 & 7,25 & 2 & 7,5 & Bredde nordside & 4,55 \\
\hline 3 & 6,25 & 3 & 6,5 & & & Under (nord?) & 3,92 \\
\hline 4 & 9,25 & 4 & 9,25 & 3 & 9,25 & Lengde østside, tverrmål? & 5,81 \\
\hline 4 & 5,175 & 4 & 5,175 & 3 & 5,175 & Bredde østside & 3,25 \\
\hline 5 & 9 & 5 & 9 & 4095 & 9 & Lengde, under øst, tverrmå? & 5,65 \\
\hline 5 & 7 & 5 & 7 & 4095 & 7 & Bredde, under øst & 4,39 \\
\hline 5 & 9 & & & & & Høyde øst & 5,65 \\
\hline 6 & 5 & & & & & Bredde vestside & 3,14 \\
\hline 7 & 6,25 & & & & & Under (vest) & 3,92 \\
\hline 7 & 7 & & & & & Høyde vest & 4,39 \\
\hline Kjølen & 7 & 6 & 7 & & & Lengde kjølen & 4,39 \\
\hline Kjølen & 0,5 & 6 & 0,5 & & & Bredde kjølen & 0,31 \\
\hline Tykkelse & 12 & & 12 & & & Tykkelse (lengde N-S) & 7,53 \\
\hline Høyde S & 5,5 & & & & & Høyde sør «fra grunden» & 3,45 \\
\hline 0 Oven til & 6,25 & & & & & Bredde & 3,92 \\
\hline
\end{tabular}

Tabell 1: Aagaards mål fra 1708 av

Kongssteinen i Stavanger. Det er litt forskjellige opplysninger på kartet og de to tegningene han laget - det kjente 1726-kartet og to tegninger fra 1736, hvorav én i Det Kongelige Bibliotek i København (her kalt B 1736 K) og én i Deichmanske bibliotek i Oslo (C 1736 D). Aagaard anga målene $i$ sjcellandske alen $(=62,7707 \mathrm{~cm})$. Det er teoretisk mulig a gjenskape steinen, men her har vi nøyd oss med en plantegning som antyder bredden på flatene og himmelretninger. Merk at Aagaards «lengde» enten må vare et tverrmål av flaten eller følge

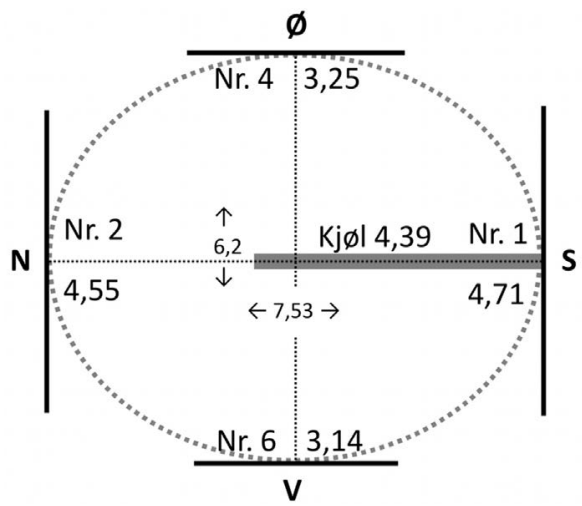
dens kurvasjon. Ø-V tverrmål etter Christie $i$ 1828. Steinen var 5,65 m høy $i$ øst. 
straks, at den ikke hørte hjemme i disse omgivelser, som den laa der i sin ensomme storhed med bare flade marker rundt omkring sig (Giverholt 1899:84).

Gateplanet der Kongssteinen sto, er 27,4 moh. Den lå 23 m over og 205 m unna Breiavatnet. ${ }^{31} \mathrm{Vi}$ setter toppen av steinen til $33 \mathrm{moh}$. Vi tar utgangspunkt $\mathrm{i}$ at steinen ikke var omgitt av store trær da navnet ble til. Strandforskyvningen de siste 2000 år setter vi til ca. $2 \mathrm{~m}$, altså ca. $1 \mathrm{~m}$ per tusen år. Vi regner 1,7 m i strandforskyvning fra 300-tallet, da gården ved Breiavatnet ifølge Simonsen ble ryddet og landskapet åpnet.

Vi lager én lang og én kort siktlinje fra Vågen (figur 13 og 14). I det første eksempelet står våre «avatarer» i en båt midt i Vågen utenfor Valberget og skuer opp mot Kongssteinen i sør (SSØ). I det andre eksempelet står paret innerst i Vågen på dagens fisketorg og ser i samme retning. Den lange siktlinjen er $760 \mathrm{~m}$, den korte $545 \mathrm{~m}$ (litt over i skrå luftlinje). Synshøyden er satt til 1,5 m. I begge tilfeller har paret fri sikt til steinen. Den har dessuten fri horisont bak, og var slik lett å få øye på. Sett fra Valberget ville Storhaug og det høye

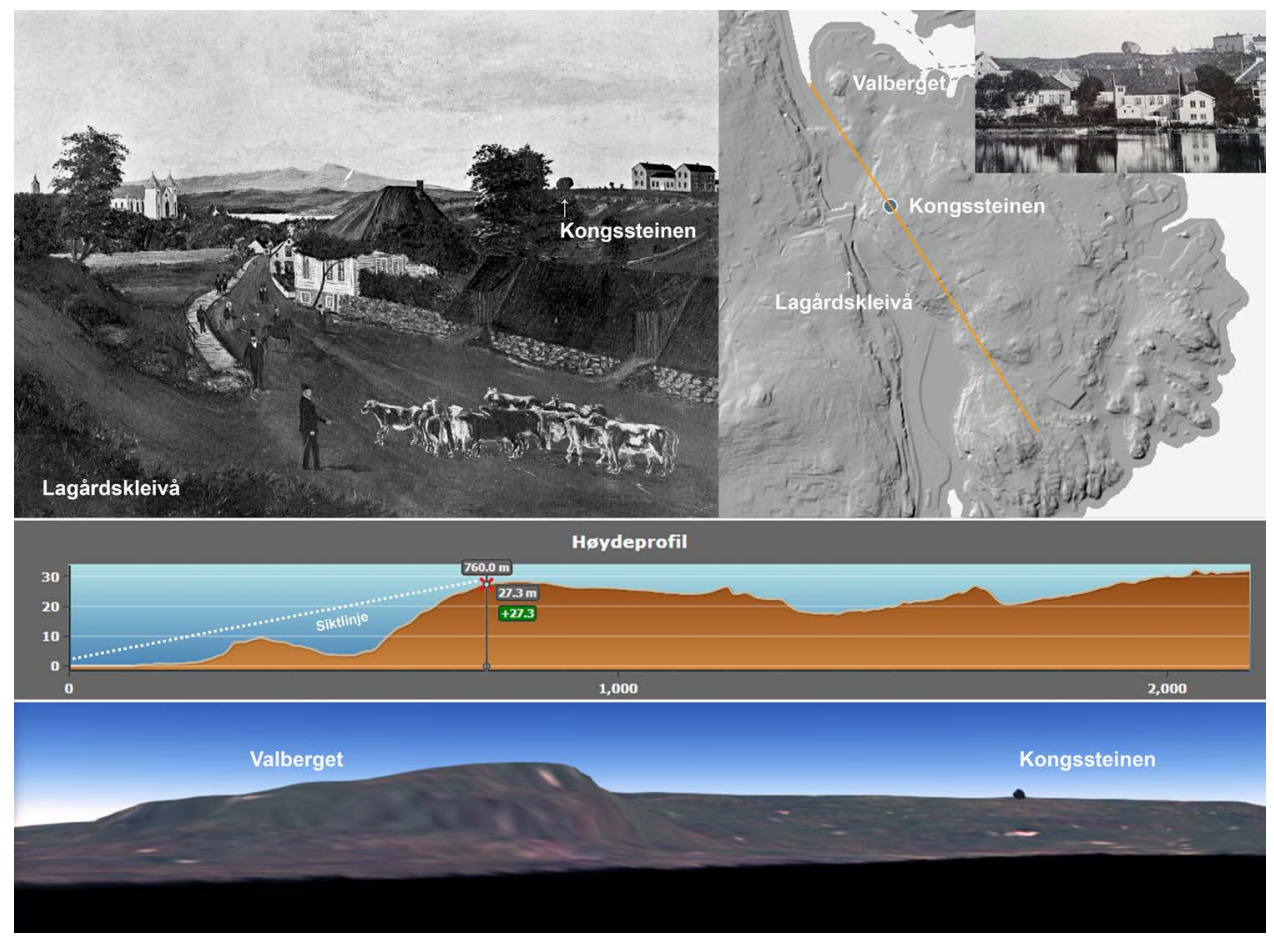

Figur 13: Lang siktlinje fra Vågen og Kongssteinens plassering i landskapet. Øverst til venstre Suchofs maleri fra 1854 med Kongssteinen til høyre i bildet. Det er ca. $350 \mathrm{~m}$ fra Lagårdskleivå til Kongssteinen. Til høyre siktlinje og landskap fra Vågen til Kongssteinen, $760 \mathrm{~m}$ avstand. Øverst til høyre foto av Kongssteinen fra ca. 1860 (etter Henriksen 1953 [1908]:137). Nest nederst terrengprofil, sammentrykt. Forholdet mellom høyde og lengde er 1:10. Terrengmodellen er basert på data fra Hoydedata.no, Statens kartverk. Nederst sikten fra Vågen mot Valberget og Kongssteinen. Valberget minner lite om en stav. 3D-modell av Ermias Beyene Tesfamariam. Illustrasjon: Frode Iversen. 
Lifjellet øst for Gandsfjorden komme bak den (Figur 14, øverst). Mine tester viser at fra sjøen i en avstand på 500-750 m var steinen best synlig fra Vågen. Fra Østervåg ble sikten brutt av høydedraget for St. Petri. Fra Fiskepiren brytes sikten så vidt av bakkedraget straks sør for krysset for Kongssteinsgata og Hetlandsgata. Fra Hillevågsvatnet var det ikke mulig å se steinen på Risberget. Terrenget stiger for bratt. Arkitekt Schiertz' skisse fra 1842 fra toppen av Kongssteinen viser likevel utsyn til fjorden mot nord, slik også Giverholt (1899:84), «Lille Marius», forteller: «og der sad jeg nu for sidste gang og saa udover fjorden».

Fra fjorden i nord (ved Sølyst) var Kongssteinen etter min beregning synlig fra ca. $900 \mathrm{~m}$ avstand, neppe nærmere på grunn av terrengets stigning. Innsynet fra nord var heller ikke så imponerende. Det var stor avstand, fjell i bakgrunnen og synlighet fra bare noen posisjoner. Utsynet fra Kongssteinen over fjorden ville likevel være storslagent. Fra Vågen ville Kongssteinen se mer «majestetisk ut» på grunn av vinkelen, kortere avstand og fri horisont

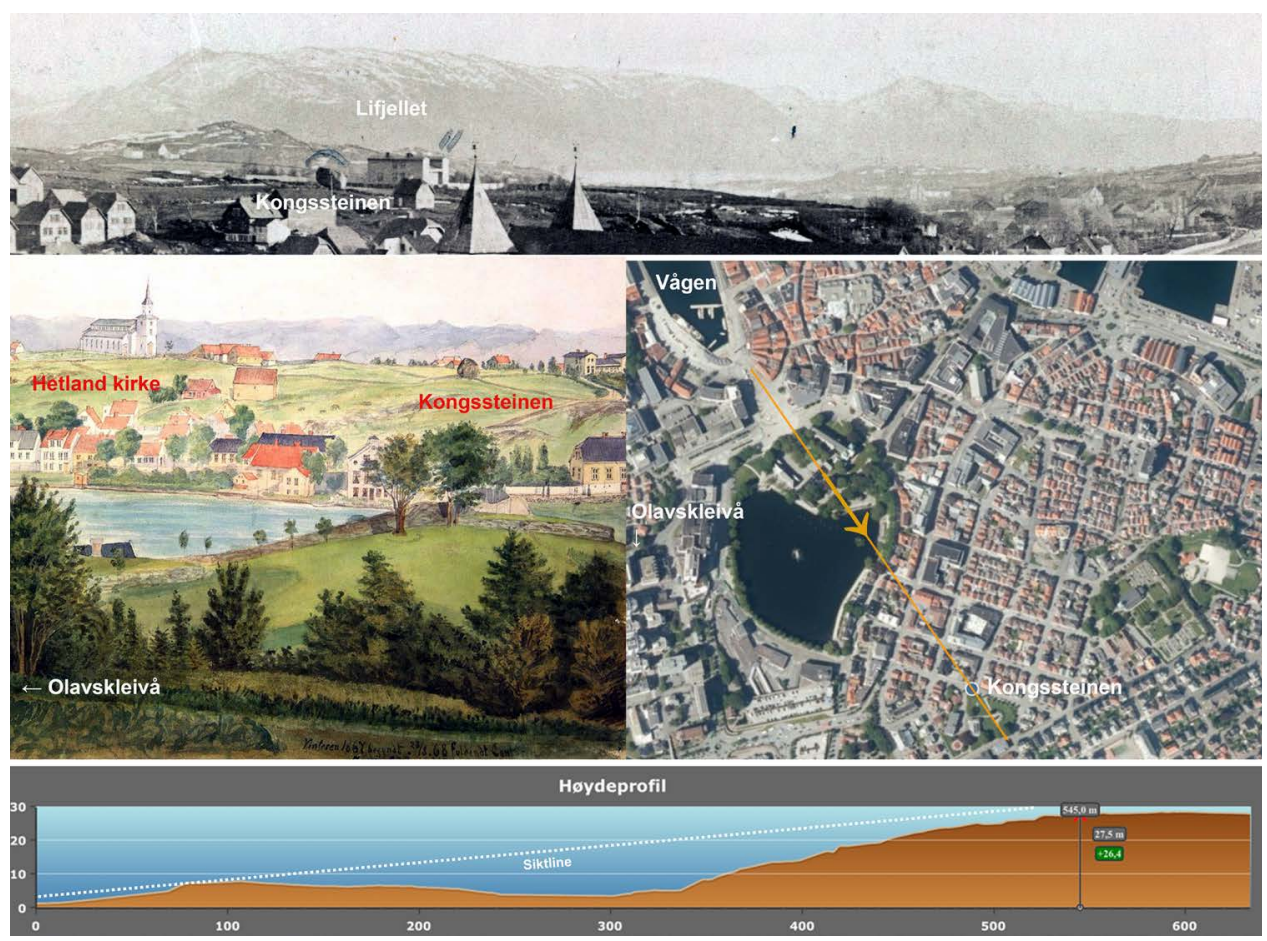

Figur 14: Kort siktlinje fra Vågen og Kongssteinens plassering i landskapet. Til venstre i midten Gabriel Monsens maleri «Mot Bergeland» fra 1871 med Kongssteinen til høyre i bildet, ca. 550-575 m unna maleriets nullpunkt, litt sørøst for Olavskleivå. Til høyre i midten siktlinje fra Vågens bunn mot Kongssteinen, $545 \mathrm{~m}$ avstand. Nederst terrengprofil, sammentrykt. Forhold mellom høyde og lengde er 1:2. Terrengmodellen er basert på data fra Hoydedata.no, Statens kartverk. Øverst Kongssteinen fotografert fra Valbergstårnet ca. 1867. Utsnitt av foto, Stavanger byarkiv. Illustrasjon: Frode Iversen. 
bak. Fra markene og gårdene på Hetland, Våland og Eiganes var Kongssteinen godt synlig. Den var et velkjent landmerke som lå litt lavere i terrenget. Det er et sentralt poeng at Kongssteinen fra sjøen var best synlig nettopp fra Vågen. Beregninger i 3D-modellen viser at den herfra i februar hadde lav morgensol bakom og dermed sto seg spesielt ut i motlyset.

Høy løvskog ville eventuelt ha endret inntrykket vesentlig. Eiketrær kan bli 30-40 m høye. Så høye trær ville potensielt skjule både Valberg på 29 moh. og Kongssteinen på 33 moh. Beregningen viser at Kongssteinen ville være synlig fra Vågen 760 m unna med inntil $6 \mathrm{~m}$ høye trær på brinken mellom Breiavatnet og Torvet. Fra Fisketorget ville den da være skjult.

\section{Konklusjon}

I denne artikkelen har jeg fremsatt en ny og noe dristig tolkning av navnet Stavanger. Faghistorisk har diskusjonen dreid seg om hvilke topografiske elementer navnet har sin bakgrunn i. Hvilken fjord og hvilken stav viser navnet til? Jeg har vurdert tidligere forslag og finner Knut Helles forklaring mest plausibel. Han mente at Valberg var staven i navnet og Vågen fjorden. Jeg slutter meg til at Vågen var fjorden, men har vurdert en annen stav, nemlig Kongssteinen på Risberget ovenfor Breiavatnet. Begge forslagene forutsetter et åpent landskap fritt for høye trær og skog. Bare da fikk de topografiske elementene tilstrekkelig «visuell kraft» til å være navngivende for fjorden.

Kongssteinen var en massiv kampestein, 7,5 x 6,2 m og 5,6 m høy. Den sto øverst på Risberget 27,4 moh. Fra Vågen var det fri sikt til denne bemerkelsesverdige naturformasjonen som var grensestein for de to sentrale gårdene i området, Eiganes og Hetland. Omkring Breiavatnet ble en gård ryddet og landskapet åpnet på 300-tallet. Det er lite arkeologisk kunnskap om bosetningene på Eiganes, Hetland og Våland, men trolig fantes alle i eldre jernalder da navnet Stavanger ble til som et fjordnavn. Med etablering av én eller flere gårder i området ved Breiavatnet i eldre jernalder oppsto trolig et behov for å definere grensene. Trolig ble Hetland fradelt en større gård (Eiganes). Kongssteinen ble grensemerket - staven mellom dem.

Stedsnavn er ofte dannet på bakgrunn av spesielle og karakteristiske topografiske trekk. Kongssteinen var mer bemerkelsesverdig enn Valberg. Vågen var det eneste stedet fra sjøen hvorfra Kongssteinen var synlig fra relativt nært hold. Fra denne lille fjorden kunne lokalbefolkningen se den karakteristiske steinen, som de visste var en grensestav. Den lå i glaningen. Det kan ha vært årsaken til at akkurat denne fjorden fikk navnet Stavanger. Kunnskapen var lokal. Navnetradisjonen var sterk nok til at navnet på 900-tallet festet seg på «utvekslingsstedet» som ble til byen Stavanger. Fra brinken ved Breiavatnet så byborgeren en våg og havn. Det ble også nødvendig å skille bynavnet fra fjordnavnet. Fjordnavnet Stavanger forsvant og ble erstattet av Vågen. Det forslaget som er fremsatt, har fordelen av å forklare navnet Stavanger som dannet av en primær betydning av ordet stav, som appellativ for «grensemerke», altså noe som er en stav, ikke i overført betydning om noe som ligner en stav. 


\section{Takk}

Forskning er et lagspill på tvers av tid og rom. Medspillerne kan gi deg presise pasninger, også når de er borte. Jeg er dypt imponert over det store arbeidet som er nedlagt i Stavanger bys historie av kollegaer de siste hundre år og mer. Respekt og takk. Det som måtte være av ære deles med dem. Jeg vil også få takke redaksjonen i Viking og fagfeller for gode innspill. Arkeolog Jan Brendalsmo takkes for hjelp og innspill underveis og Jarle Christensen, Storhaug, for på kort varselå ha rykket ut og talt og fotografert stabbesteinene i Paradissvingen for meg. Ingrid Iversen og Ragnhild Dreyer takkes for bilder av Klovsteinen på Eiganes. Takk til tidligere arkivregistrator Ester Olstad ved Statsarkivet for transkribering av Aagaards håndskrift på 1726-kartet og Silje Ildgruben ved Stavanger byarkiv for god hjelp med illustrasjoner. Ikke minst skal senioringeniør Ermias Beyene Tesfamariam, KHM, UiO ha en særlig stor takk for hjelp med 3D-modellen av Kongssteinen og landskapet rundt Stavanger. Jeg vil også få takke professor Klaus Johan Myrvoll, Universitetet i Stavanger, for viktige filologiske innspill, forsker Henrik Svensen, Universitetet i Oslo, for en vurdering av geologien ved Valberget og forskningsbibliotekar Espen Karlsen, Nasjonalbiblioteket, for hjelp med tolkningen av Torfæus' latinske tekst.

\section{Etterord - Kongssteinens skjebne}

Kongssteinen endte opp som blant annet stabbesteiner i Hillevåg. Opplysninger om dette har vi fra maskinist Bjørn Hultman (1885-1965), som var øyenvitne til sprengningen av siste rest av Kongssteinen i 1890-årene (Stavanger Aftenblad 12. oktober 1954, side 3). Stabbesteinene fikk stå på rekke og rad langs Paradisveien ved Hillevågsvatnet i 70-80 år før de ble fjernet. På ortofoto fra 1960 kan det telles rundt 170 stabbesteiner. I 1968 sto ca. 35 tilbake, og i 1973 var alle vekk. Dersom Stavanger by ønsker et minnesmerke over Kongssteinen, kan man spore opp noen av disse stabbene og bruke dem. De 40 steinene som står i Paradissvingen, er oppført på samme tid, og stammer kanskje også fra Kongssteinen.
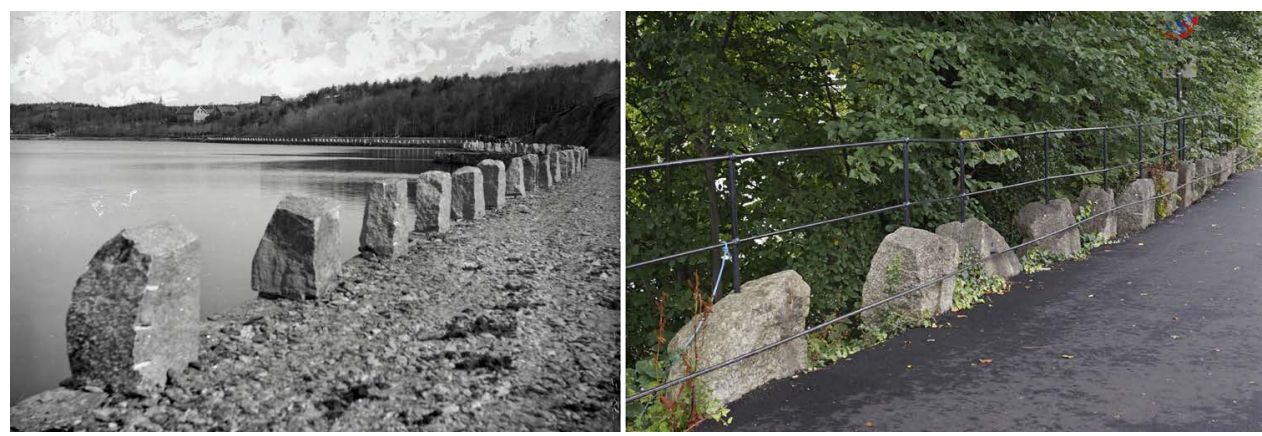

Til venstre: mange små «kongssteiner» på rekke og rad ved Paradisveien, Hillevågsvatnet, omkring 1890. De er i dag borte. Foto: Carl Johan Jacobsen, Stavanger byarkiv. Til høyre: omkring 40 stabbesteiner er bevart i Paradissvingen og kan vare fra Kongssteinen.

Foto: Jarle Christensen. 


\section{ORCID}

Frode Iversen https://orcid.org/0000-0001-6880-7730

\section{Litteratur}

Austbø, Anne Tove, Elisabeth Hovland, Gunnar M. Roalkvam, Lene K. Hoff, Liselotte Nes Høiland, Elise Norland Sørheim, Torkel Thime, Øyvind Wigestrand (red.) 2008 Stavanger byleksikon. Wigestrand, Stavanger.

Bang-Andersen, Sveinung 2016 Kongssteenens Faciat, Accurate Maal og Beskrivelse. Stavangeren 2016/3:32-34.

Bing, Lars Hess 1796 Beskrivelse over Kongeriget Norge, Øerne Island og Fcerøerne, samt Grønland, efter ældre og nyere, trykte og haandskrevne geographiske, chorographiske.forfattet $i$ alphabetisk Orden. Gyldendals Forlag, Kiøbenhavn.

Bjorvand, Harald og Fredrik Otto Lindeman 2007 Våre arveord. Etymologisk ordbok. Novus forlag, Oslo.

Brendalsmo Jan og Knut Paasche 2017 Stavanger - før det ble en by. Historisk tidsskrift 96:103-123.

Bringsfjord, Finn 2009 Stavanger og staven. Stavangeren 1:6-18.

Brøgger, Anton Wilhelm 1912 Et Stavangerkart fra 1726 - Et bidrag til Stavanger bys historie. I Stavanger Aftenblad, i to deler 15. juni 1912:6-7, 18. juni 1912:2 og 26. juni 1912:4 (sidene er upaginert). Stavanger.

1915 Stavangers historie i middelalderen. Dreyers forlag og boktrykkeri, Stavanger.

Bærheim, Anders

1953 Tre gamle merkesteiner i Eiganesmarka. Ætt og heim:62-65.

1959 En markegangsforretning mellom Bispelagård og Hetland prestegård 1686 på gården Eikanes. Stavanger museum årbok 1958:85-102.

Bull, Edvard

1920 Leding: militcer- og finansforfatning $i$ Norge $i$ ældre tid. Steenske forlag, Kristiania og København.

de Fine, Bendix Christian

1952 Stavanger Amptes udførlige beskrivelse: med eit tillegg. Utgitt av Per Thorson. Rogaland historie- og ættesogelag, Stavanger.

Denham, Sean Dexter

2014 Commingled human remains from Stavanger Cathedral. I Berit J. Sellevold (ed.) Old bones: osteoarchaeology in Norway: yesterday, today and tomorrow, s. 117-136. Norsk institutt for kulturminneforskning, Oslo.

Düwel, Klaus

1983 Runenkunde. Springer-Verlag, GmbH Deutschland.

Eikeland, Berner

1957 Gardsgrensene i Gyland. Agder historielag, Kristiansand.

Eilertsen, Krister Scheie

2017 Bosetningsspor på Våland i Stavanger. Frá haug ok heiðni 4:8-12.

Elgvin, Johannes

1956 En by i kamp. Stavanger bys historie 1536-1814. Stavanger kommune, Stavanger.

Engen Sigleif

1955 Ja, hvor lå Staf-angr? Stavanger Aftenblad 28.05.1955:6.

Enoksen, Johanne, Johanne Margrethe Johnsen, B. J. Borrevik, Gustav Christiansen, P. Ree Pedersen (red.) 1944 Festskrift til søndagsskolens 100-års jubileum 1844-1944. Dreyers grafiske anstalt, Stavanger. 
Erichsen, Andreas Emil

udat. [ca. 1905] Stavanger ncerings- og forretningsliv i tekst og billeder. A. M. Hanchs boktrykkeri og forlag, Kristiania.

1906 Samlinger til Stavangers historie 2. Dreyers bogtrykkeri, Stavanger

Ersland, Geir Atle og Arne Solli

2012 Stavanger bys historie 1. Bispesete og borgarby - frå opphavet til 1815. Wigestrand, Stavanger.

Flokenes, Kåre

1999 Stadnamn i Askvoll. Erling Skjalgssonselskapet, Stavanger.

Frafjord, Reidar

2009 Stavanger - navnet kommer av formen på fjorden. Stavangeren 1:23-26.

Giverholt, Jens Marius

1899 Fra Skoledagene. Erindringer af Carolus. Fr. Nygaards Forlag, Bergen.

Glare, P.G.W.

1982 Oxford Latin dictionary. Oxford University Press, Oxford.

Gundersen, Ingar Mørkestøl

2019 The Fimbulwinter theory and the 6th century crisis in the light of Norwegian archaeology:

Towards a human-environmental approach. Primitive tider:101-119.

Heggstad, Leiv, Finn Hødnebø og Erik Simensen

1975 Norrøn ordbok. 3. utg. Det Norske Samlaget, Oslo.

Helle, Knut

1975 Stavanger - fra våg til by. Stavanger kommune, Stavanger.

Helliesen, Tor

1900 Registreringer. Stavanger Museum Aarshefte 1900:33-96.

Henriksen, Christian

1953 [1908] Stavanger $i$ svundne dage. Dreyerske forlag, Stavanger.

Hodne, Kåre Oddleif

1986 Grågås: Stavanger stifts og domkapitels jordebok ca. 1620. Agder historielag og Statsarkivet i Kristiansand. Kristiansand.

Holm, Gösta

1991 De nordiska anger-namnen. Det Norske Videnskaps-Akademi. II. Hist.-Filos. Klasse. Skrifter. Ny Serie No. 18. Lund University Press, Lund.

Hovda, Per

1964 Stavanger og nokre andre namn. Stavanger Museum årbok 74:77-83.

Hovstad, Håkon

1980 Gårdsgrenser. Et bosetningshistorisk hjelpemiddel? Inst. for sammenlignende kulturforskning, serie B, skrifter LXII, Oslo.

Imer, Lisbeth

2015 [2007] Runer og runeindskrifter: Kronologi, kontekst og funktion i Skandinaviens jernalder og vikingetid. Ph.d. avhandling, Det Humanistiske Fakultet, Københavns Universitet.

Indrebø, Gustav

1935 Fjordung: granskingar i eldre norsk organisasjons-soge. Bergens Museums Aarbok 1934:1. Bergens Museum, Bergen.

Iversen, Frode

2008 Eiendom, makt og statsdannelse: kongsgårder og gods $i$ Hordaland i yngre jernalder og middelalder. Universitetet i Bergen Arkeologiske skrifter, UBAS, Nordisk 6, Bergen.

2017 Estate division: social cohesion in the aftermath of AD 536-7. I The Agrarian Life of the North $2000 B C-A D$ 1000. Studies in Rural Settlement and Farming in Norway, redigert av Frode Iversen og Håkan Petersson, s. 41-75. Cappelen Damm, Oslo.

2019 The Thing and the King: The formation of the Norwegian Medieval Kingdom, I Julio Escalona Monge; Orri Vésteinsson \& Stuart Brookes (eds.) Polity and Neighbourhood in Early Medieval Europe, s. 147-172. Brepols, Turnhout. 
Johnsen, Ingrid S.

2017 Strandforskyvning på Bokn og deglasiasjonen av Boknafjorden Rogaland. Upublisert masteroppgave, Universitetet i Bergen.

Kitson, Peter R.

1994 Quantifying Qualifiers in Anglo-Saxon Charter Boundaries. Folia Linguistica Historica XIV (for 1993):29-82.

Kjær, Albert og Oluf Rygh

1919 Nordre Bergenhus Amt. Norske Gaardnavne oplysninger samlede til brug ved matrikelens revision 12. W.C. Fabritius \& sønner A/S. Kristiania.

Kolsrud, Oluf

1925 Stavanger bispestol. I Jan Petersen (red.), Stavanger 1125-1425-1925, s. 37-84. Stavanger kommune, Stavanger.

Lexow, Jan Hendrich

1975 Stavanger ved inngangen til det 19. århundre. I Per Barkved, Rolf Danielsen og Torgils Våge (red.) Stavanger på 1800-tallet, s. 9-86. Stavanger kommune, Stavanger.

Lillehammer, Arnvid

2000 Rapport om forprosjektet mellomalderbyen Stavanger. Spørsmål om grunnlegginga av Stavanger by. AmS-Rapport 16, Stavanger.

Lous, Carl

1868 En stavangersk Cicerone. M. C. Lønnings forlag, Stavanger.

Love, Jeffrey, Inger Larsson, Ulrika Djärv, Christine Peel og Erik Simensen

2020 A Lexicon of Medieval Nordic Law. Open book publisher, Cambrigde.

Magerøy, Hallvard

1988 Soga om birkebeinar og baglar. Del 1. Solum forlag, Oslo.

Marstander, Carl J. S.

1953 De nordiske runeinnskrifter i eldre alfabet. Viking 16:1-277.

Midbrød Arvid

1960 Staven i Stavanger-navnet og i andre stedsnavn. Ætt og heim:51-52.

Molbech, Christian

1833 Dansk Ordbog, første del A-L. Gyldendalske Boghandlings Forlag, Kiöbenhavn.

Munch, Peder Andreas

1943 [1855] Det norske folks historie 6. Instituttet for historisk forsking, Oslo.

Myhre, Albert

1953 Stabsto. Ætt og heim:45-58.

Nes, Oddvar

1976 Fjordnamn. Norsk Stadnamnleksikon, utgitt av Jørn Sandnes og Ola Stemshaug, s. 38-41. Det norske samlaget, Oslo.

Nissen, Kristian

1962 Stavanger-kartografen Ulric Frideric Aagaard, en middelmådig kartograf, men fortrinlig kartkopist. Stavanger museum Arbok 72:127-164.

Næss, Hans Eyvind

2009 Steglebakken. Stavangeren 1/2009:29-47.

Olsen, Magnus

1926 Ættegård og helligdom, norske stedsnavn sosialt og religionshistorisk belyst. Oslo.

Petersen, Jan

1925 Stavanger 1125 -1425-1925. Dreyer grafiske anstalt, Stavanger.

Rygh, Oluf

1896 Norske Fjordnavne. I Sproglig-historiske Studier tilegnede Professor C. R. Unger, s. 30-86. Aschehoug, Kristiania.

1898 Forord og innledning. Norske Gaardnavne. Oplysninger samlede til brug ved matrikelens revision. W.C. Fabritius \& Sønners Bogtrykkeri, Kristiania. 
Røys, Johan Endresen

1952 Det var i de tider. Moes Aktietrykkeri’s forlag, Stavanger.

Thorson, Per

1952 Merknader. I Bendix Christian de Fine Stavanger Amptes udførlige beskrivelse: med eit tillegg.

Utgitt av Per Thorson, s. 174-282. Rogaland historie- og ættesogelag, Stavanger.

Semple, Sarah, Alexandra Sanmark, Frode Iversen, Natascha Mehler med Halldis Hobæk, Marie Ødegaard og Alexis T. Skinner

2020 Negotiating the North. Meeting-Places in the Middle Ages in the North Sea Zone. Routledge. Oxford.

Simonsen, Asbjørn

1971 Breiavatnet og Stavangers eldste historie. Stavanger Museum Arbok 1971:39-49.

2013 Rusk i byens blinkende øye. Hva bunnslammet i Breiavatnet kan fortelle om Stavangers tidlige historie. Stavangeren 3:5-16.

Simonsen Selvald

1972 Hetlandsmarkens historie. Ætt og heim:51-62.

Solheim, Ludvig

1940 Stavanger og nermaste oppland i gamal tid. Rogaland historielags årsskrift 1940:6-12.

Stemshaug, Ola

1985 Namn i Noreg. Ei innføring i norsk stadnamnsgransking. Det Norske Samlaget, Oslo.

Storm, Gustav

1895 Historisk-topografiske Skrifter om Norge og norske Landsdele, forfattede i Norge i det 16de Aarhundrede. Udg. For Det norske historiske Kildeskriftfond, Christiania.

Særheim, Inge

1999 Namn og gard studium av busetnadsnamn på -land. Upublisert avhandling for dr. philos-graden. Universitetet i Bergen.

2007 Stadnamn i Rogaland. Fagbokforlaget, Bergen.

Torfæi, Tormodi

1711 Historia Rerum Norvegicarum 1. Christian Reizer, Hafniæ (København).

Torfæus, Tormod

2008 [1711] Norges historie 1. Eide forlag, Bergen.

\section{Forkortelser}

DN = Diplomatarium Norvegicum I-XXIII. C.C.A. Lange, C.R. Unger mfl. 1847-2011. P. T. Mallings Forlagshandel, Norsk historisk kjeldeskrift-institutt, Riksarkivet, Christiania/Oslo.

$\mathrm{G}=$ Gulatingsloven.B.Eithun,M.Rindal,T.Ulset(red.)1994.Deneldre Gulatingsloven . Oslo: Riksarkivet / Robberstad, Knut (red.) 1981. Gulatingslovi. Fjerde utgåva. Norrøne bokverk 33. Det norske Samlaget, Oslo.

ID = nummer i Askeladden, Riksantikvarens kulturminnedatabase http://askeladden ra.no

$\mathrm{NG}=$ Norske Gaardnavne oplysninger samlede til brug ved matrikelens revision I-XIX, Kristiania.

$\mathrm{NgL}=$ Norges gamle Love indtil 1387 1-5 (utg. Gustav Storm og Ebbe Hertzberg), Christiania.

NiYR $=$ Norges innskrifter med de yngre runer 3, utgitt ved Magnus Olsen 1954. Norsk historisk kjeldeskrift-institutt, Oslo.

NRR $=$ Norske Rigs-Registranter - tildeels i Uddrag (1861-1891), Christiania

$\mathrm{RN}=$ Regesta Norvegia. Gunnes, Erik med flere (red.) 1989-. Norsk Historisk Kjeldeskrift-Institutt, Oslo. 


\section{Noter}

1 Ved referanse til «Ersland og Solli 2012» er det Geir Atle Ersland som er kapittelforfatter dersom ikke annet er oppgitt.

2 For nærmere forklaring se note 18.

3 Mål etter oppmåling 1708 i sjællandske alen (for årstallet se Nissen 1962:128).

4 Granitt, etter Røys (1952:43). Det er noe tvil om årstallet for siste sprenginng. Maskinist Bjørn Hultman, født 7. juli 1885, opplyser i Stavanger Aftenblad 12.10. 1954, side 3, at: «Jeg var øyenvitne da steinen ble sprengt, den gikk akkurat i to deler ved første sprenging.» Rektor Erichsen (udat. [ca. 1905]:73) opplyser omkring 1905 at steinen ble sprengt bort for «12-14 Aar tilbage», da trolig i begynnelsen av 1890-årene.

5 3D-modellen av Kongssteinen og landskapet rundt Stavanger er utarbeidet av Ermias Beyene Tesfamariam og Frode Iversen og finnes på nettside besøkt 16. september 2020: https://uio-no.maps.arcgis.com/home/webscene/viewer.html?webscene $=2$ ba3497f73ec4d39a8e1521a58b6ba35

6 Se særlig Holm (1991:82) for fyldige referanser til spesifikk filologisk forskning omkring Stavanger-navnet.

7 Noe usikker datering, se RN I nr. 628 og Helle (1975:80).

8 Navnet Brofjord på Byfjorden finnes på hollenderen Johannes Janssonius' (1588-1664) kart Nova et accurata tabula (Det Kongelige Bibliotek i København, ID 516047, KBK 2-1). Kartet har med en rekke lokale navn på øyer og fjorder omkring Stavanger: Lysefjord, Høgsfjord, Gandsfjord, Bro, Hildø, Hellesø med flere. Navnene er hentet fra eldre kart. Det bruker Oslo, ikke Christiania som byen het fra 1624. Hverken Flokenes (1999) eller Rygh (1896) har med Brofjord som eldre navn for Byfjorden.

9 At de Fine gjengir en genuin tradisjon, fremgår for øvrig også av Aagaards tegninger fra 1736. Den ene har påskriften: «Kongsteenen wed Stawanger saa kaldet fordi Hoyloft ihukomelse Konning Frideric dend 4de samme har bestegen» (København). På den andre fremgår det til og med hvor kongen sto under besøket: «... Hvor dend Høysalige Herre stod», nemlig på sørsiden av steinen (Deichmanske) (figur 4, nederst).

10 Det eldste fotografiet er privat (før 1865? ingen hus ved siden), publisert i Henriksen (1953 [1908]:137). To nokså like fotografier fra Valbergstårnet (ca. 1867, ett hus ved siden) og ett fotografi fra motsatt side av Breiavatnet (ca. 1867-1870, to hus ved siden) finnes i Stavanger byarkiv. Foto av kullstifttegning fra 1853 i Monsensamlingen, også i Stavanger byarkiv.

11 Den startet ved Lagårdskleivå og inkluderte nåværende Peder Klows gate.

12 Deler av kartet synes å ha blitt utarbeidet alt i 1801 (se kart Lexow 1975:21).

13 Jæren og Dalerne sorenskriveris pantebok nr. 13, 1835-1838. Tekst gjengitt på nettside besøkt 16. september 2020: https://www.stokka-historielag.no/dokument-fra-statsarkivet/grense-mellom-nedre-tasta-ogstokka-1835/

14 Særlig aktuelle som grensemerker er de tre flyttblokkene i Våland kolonihage med spor etter en fjerde stein. De er likevel litt ute av den naturlige linjen. På et kart fra 1855 går bygrensen parallelt på vestre side av gamle Ullandshaugvei, og krysset veien der Vålandsveien kom ned fra «Vaalandspiben» (jf. også kartet fra 1882). Bærheim må ha trukket dem for nær Vålandshaugen, og de burde ligge mer i linje med grensen på kartet fra 1830. Det er flere ansamlinger med flyttblokker i denne linjen som omtrent følger 50 m-koten (jf. kartet fra 1957).

15 Se Bærheim (1959:98) for nærmere diskusjon om grensesteinene mellom Auglend og Lagård.

16 1571: Riksarkivet, Rentekammeret, Realistisk ordnet avdeling, benificeret gods, 2 og 1574 NRR II:113-114.

17 Stavanger stift = Rogaland, Agder, Valdres og Hallingdal, samt Eidfjord sogn. Tallene er beregnet med utgangspunkt i opplysninger i Norske Gaardnavne: Stavanger amt 2621, Lister og Mandal 2425, Nedenes amt 1831, Hallingdal med Eidfjord $1042+38$, Valdres 1178 .

18 På latin: «nomen a vicio scopulo, Staf dicto, \& vocabulo angur / priscâ lingva mare significante, adeptum» (Torfæi 1711:64). Scopulos har etter P.G.W. Glares standardverk Oxford Latin Dictionary en annen betydning enn «skjæret» i den norske oversettelsen (Torfæus 2008 [1711]:171). Scopulus har primærbetydningen «a projecting rock (in the sea, on the coast)», altså noe man peiler etter (Glare 1982:1708). Omkring 1760 koblet klokker Hans Smidt opplysningen hos Torfæus til skjæret i Østervåg (Stavanger Steen) (Erichsen 1906:44). Det samme gjorde trolig også de Fine (1743), som likevel ikke henviser direkte til Torfæus i sin tekst (de Fine 1952:62) (se utgiverens kommentar, Thorson 1952:212). Det er uklart hva Torfæus baserte seg på. Han brukte ikke Peder Claussøn Friis her, som ofte ellers. Friis gjengir nemlig Beyers teori som vi siterte innledningsvis, men det gjør ikke Torfæus. Vi må være åpne for at «Stavanger Steen» kan være en tolkning gjort av de Fine og Smidt. Sistnevnte tvilte dessuten på at opplysningen var riktig. Men Torfæus kan ha ment et sjømerke, et nes, 
berg, stein. Hverken Hans Smidt (1711-1788), som kom til Stavanger i 1741, eller de Fine (1696-1746), som ble utnevnt til amtmann i Stavanger amt i 1725, møtte Torfæus personlig (død 1719). De kan ha tolket Torfæus' tekst feil og selv gjort koblingen til skjæret, som var godt kjent i Stavanger. Allerede Aagaards kart fra 1726 viser at skjæret ble kalt Stavanger Steen.

19 Helle opererer med en vestre og en østre Eiganes. Dersom skillet fulgte Eiganesveien (nordgrensen for Kanniket), blir hans vestre lik min nordre, og østre lik søndre.

20 Den må da trolig ha fulgt sognepresten i Mariakirken i middelalderen, dernest sognepresten i Domkirken etter reformasjonen, senere sognepresten i Vår Frues kirke, Hetland. En kort periode rett etter reformasjonen lå den til lagmannen.

21 Helle (1975:41) regner ikke Våland som en gammel gård, men har ikke kommentert at Lagård må være et ungt navn. Særheim (2007:263) fører opp Våland «... som namn på eit bystrok (og bruksnamn) i Stavanger, under Bispelagård ...». Våland tilsvarer nordre del av Bispelagård, som også omfattet husmannsplassen Hillevåg i sør. Det er ikke kjent hvorvidt Hillevåg opprinnelig var en del av en større Våland-gård. Vurdert etter Hillevågens beliggenhet anser jeg det som det mest sannsynlige, og tolker dette slik at Våland i realiteten var et eldre navn på Lagård. Sigleif Engen (1955:6) har foreslått at Stavanger var et eldre navn på gården Lagård, men det har ikke støtte i kildene.

22 Merk at Liestøl fremsatte sitt forslag «... med dei sterkaste atterhald» på grunn av skadene på innskriften. Det gjaldt særlig tolkningen av det vanskelige midtpartiet (NiYR III:257).

23 Håkon Hovstad finner direkte referanse til stavsto i 23 diplomer (bare 10 bind av DN er undersøkt, IV-XIII). Det dreier seg om overdragelse av eiendom der grenser beskrives (Hovstad 1980:44).

24 Det eldste belegget, fra 679 e.Kr., har formuleringen «the very well-known bounds» (oversatt fra latin). Det er for øvrig Englands eldste originale diplom: S8 i Online catalogue of Anglo-Saxon Charters.

25 Kitson (1994:37-42) har gått grundig inn i den romaniserte etymologien omkring hoarstones og konkluderer overbevisende med at det betyr «grå stein», hverken mer eller mindre.

26 For andre forslag henviser jeg til Flokenes' (1999) nyttige utredning. Jeg er uenig i hans syn om rette strandlinjer. Han har rett i at strandlinjen på sørsiden av Staveneset har langt renere farvann enn nordsiden. Etter mitt syn er det ikke sannsynlig at dette ga navn til fjorden. Hverken Flokenes eller Helle har vurdert kulturelle grenser i området. Derfor blir våre tolkninger ulike.

27 Skipreidegrensen synes å ha blitt endret etter 1520 slik at Kinn sogn gikk inn i Brandsøy skipreide. Alt i 1320årene sognet presten på Kinn til fjerdingskirken på Bru (DN VII nr. 98). Dermed synes det ikke å være sammenfall mellom de kirkelige og verdslige inndelingene her.

28 På nordsiden av Stavaneset gikk grensen fra fjorden til fjellet via Moldkleivå ved Moldvika om lag midt på halvøya. Grensen fulgte skillet mellom bruket Stavestranda gnr. 117,2, utskilt fra Svanø gnr. 117 (NG XII:372), og Øvre Grimeli gnr. 1 i Askvoll. Førsteleddet i Grimeli kommer av Grima som ifølge Norske Gaardnavne «kunde være et Ord, der betyder Grænse» (NG XII:244). På fjellet gikk grensen østover og langsetter toppene Toreheia (707) og Ytrevågefjellet (667). Mot sør grenset Svanøy mot Stavanger gård (gnr. 11) og kanskje også Yndestad (gnr. 10).

29 Flokenes (1999:27) opplyser at det i dette området var noen topper, *Stavane, med Odd Vie som hjemmelsmann. De skal ha ligget øst for stedsnavnet Staveneset (sic) på Yndestad.

30 Det kan være noe tvil om dette er målt fra bakken, da vestre del av Kongssteinen «hang» fritt og hadde en flate under på 3,92 m. Jf. mål flate 7 .

31 Her er Aagaards mål på 1726-kartet helt feil, henholdsvis 30 og 31 sjællandske fot fra fundamentet til Breiavatnet i høyde og luftlinje. Det heter: «Steneens Perpendicular Høyde fra sit fundament til Bredvandet er 30 sedlandske foed, og fra vaagen 31 foed horizontal» $(9,4 \operatorname{og} 9,7 \mathrm{~m})$. Det kan ikke under noen omstendigheter stemme. 
